\title{
The effect of musical interventions in improving short-term pain outcomes following total knee replacement: a meta- analysis and systematic review
}

Rongguo Yu, Youguang Zhuo, Eryou Feng, Wulian Wang, Wentao Lin, Feitai Lin, Zhanglai Li, Liqiong Lin, Lili Xiao, Haiyang Wang, Yuting Huang, Chunlin Wu and Yiyuan Zhang*

\begin{abstract}
Background: A growing number of patients continue to receive total knee replacement (TKR) surgery. Nevertheless, such surgeries result in moderate to severe postoperative pain and difficulty in managing it. Musical interventions are regarded as a type of multimodal analgesia, achieving beneficial results in other clinical treatments. This study aims to evaluate the effect of musical interventions in improving short-term pain outcomes following TKR in order to determine a more reasonable and standard way of delivering musical intervention.

Methods: A systematic search was conducted to identify available and relevant randomized controlled trials (RCTs) regarding musical interventions compared against non-musical interventions in patients treated with TKR in Embase, MEDLINE, Cochrane Library, Web of Science, CNKI, and Wanfang Med Online up to 8 January 2020. The authors independently assessed study eligibility and risk of bias and collected the outcomes of interest to analyze. The statistical analysis was conducted using the Review Manager (RevMan) version 5.30 software.

Results: Eight RCTs comprised of 555 patients satisfied the inclusion criteria and were enrolled in the present study. The results showed no significant difference between the music and control groups in pain of the visual analog scale (VAS), during postoperative recovery room, back to the ward after surgery; anxiety degree of VAS; heart rate; respiratory rate; oxygen saturation; blood pressure, systolic blood pressure, and diastolic blood pressure. Nevertheless, significant differences were observed between the two groups in average increase in continuous passive motion (CPM) angles and LF/HF ratio (one kind index of heart rate variability).

Conclusions: Musical interventions fail to demonstrate an obvious effect in improving short-term pain outcomes following TKR. A reasonable standardization of musical interventions, including musical type, outcome measures used, outcomes measured, duration, timing and headphones or players, may improve pain outcomes with certain advantages and should be further explored after TKR.
\end{abstract}

Keywords: Total knee replacement, TKR, TKA, Knee surgery, Music interventions, Music therapy, Pain, Meta-analysis, Systematic-review

\footnotetext{
* Correspondence: rongsteer@163.com

Department of Orthopedics, Fuzhou second Hospital Affiliated to Xiamen

University, Fuzhou 350007, Fujian, China
}

(c) The Author(s). 2020 Open Access This article is licensed under a Creative Commons Attribution 4.0 International License, which permits use, sharing, adaptation, distribution and reproduction in any medium or format, as long as you give appropriate credit to the original author(s) and the source, provide a link to the Creative Commons licence, and indicate if changes were made. The images or other third party material in this article are included in the article's Creative Commons licence, unless indicated otherwise in a credit line to the material. If material is not included in the article's Creative Commons licence and your intended use is not permitted by statutory regulation or exceeds the permitted use, you will need to obtain permission directly from the copyright holder. To view a copy of this licence, visit http://creativecommons.org/licenses/by/4.0/ The Creative Commons Public Domain Dedication waiver (http://creativecommons.org/publicdomain/zero/1.0/) applies to the data made available in this article, unless otherwise stated in a credit line to the data. 


\section{Introduction}

Total knee replacement has achieved good therapeutic effects in easing pain and improving functional outcomes for patients with rheumatoid arthritis or knee osteoarthritis [1, 2]. Approximately 100, 000 TKR operations are performed each year in the UK [3]. The number of TKR surgeries has been estimated to reach over 3.45 million by 2030 and increase by more than $670 \%$ by 2030 in the USA $[4,5]$. Nevertheless, one study demonstrated that patients treated with TKR have been suffering from disproportionate pain, with $30 \%$ having moderate pain and $60 \%$ having severe pain [6]. Due to inadequate pain management following TKR, the procedure can lead to adverse outcomes such as severe anxiety, delayed convalescence, trouble with rest and sleep, reduced patient satisfaction, prolonged hospital stay, and heavier burden on healthcare [7-10]. It is a key focus of research, therefore, to improve patient satisfaction, optimize treatment, and reduce postoperation pain of TKR.

Chronic pain after TKR is caused by multiple factors such as psychological, biological, mechanical, surgical, and other factors [11-14]. Conventional studies have mainly focused on aspects of mechanical and biological using pharmacological interventions and physiotherapy $[15,16]$. However, adverse drug reactions are important factors needing consideration like vomiting, nausea, dysarteriotony, urinary retention, and respiratory depression [17]. Non-pharmaceutical interventions have been regarded as simple, valuable, and low-cost supplementary methods in managing pain [18]. In the past two decades, a growing level of awareness regarding the hidden effects of music and other non-pharmacological strategies to improve postoperative results was present for interventions during the preoperative, perioperative, or postoperative periods $[19,20]$.

Musical therapies are natural interventions embodying multiple aspects like physical, emotional, psychological, spiritual recovery, and social. The proposed interventions have little side effects and high performance-cost ratio strategies that are easy to use and apply [21]. Music can stimulate the brain's $\alpha$ waves, triggers relaxation and decreases muscular tension. It also stimulates the limbic system, leading to the release of endorphins, a type of neurotransmitter that causes a sense of well-being in humans [22]. Moreover, it can efficiently slow down the transmission of pain signals through the act of listening, alleviating the sense of pain [23], and reducing the dosage of paregoric post-surgery [24]. Listening to music stimulates the parasympathetic nervous system, restraining the action of the sympathetic nervous system, and reaching a target efficacy in easing anxiety $[25,26]$.

In practical clinic applications, nevertheless, incompatible consequences for musical interventions were present during the perioperative period, where various studies demonstrated pain relief [27-30] while others reported no significant changes [31]. Meanwhile, a number of studies carried out musical interventions solely within the operating room [30], while others applied them in post-anesthesia care units [32].

To the best of our knowledge, previous systematic reviews regarding psychological interventions in improving outcomes following TKR included musical therapy, hypnosis, guided imagery, and other different types of psychological interventions [33]. Due to its high heterogeneity, attaining a firm conclusion about the effectiveness of musical interventions in those treated with TKR is difficult. Furthermore, another meta-analysis and systematic review reported the effect of musical therapy on pain following orthopedic surgery, where musical interventions were found to relieve pain [34]. The study included a series of surgical operations when assessing the utility of listening to music after TKR, including the position of the knee, hip, shoulder, spine, and others. In similar circumstances, this study discussed improving outcomes for patients after TKR or THR [35]. The results are unconvincing because of the distinct prognosis and indications of two different surgical procedures.

Until now, no meta-analysis and systematic reviews have reported the effectiveness of musical interventions in patients who just received TKR. Due to the high incidence of pain following TKR, it may be of particular benefit to manage pain via musical interventions during the perioperative period. Therefore, a meta-analysis and systematic review was conducted to evaluate the effect of musical interventions in improving short-term pain outcomes after total knee replacement in order to ascertain a more reasonable and standard way of delivering musical interventions.

\section{Materials and methods \\ Search strategies}

This study was conformed to the Preferred Reporting Items for Systematic Reviews and Meta-Analyses (PRIS MA) [36]. Comprehensive literature searches were conducted in Embase, MEDLINE, Cochrane Library, Web of Science, CNKI, and Wanfang Med Online databases for RCTs published from the earliest available records to 8 January 2020 using the following keywords and their combinations: total knee replacement, TKR, total knee arthroplasty, TKA, music, audio, music therapy, and music interventions. Both $\mathrm{MeSH}$ and Emtree headings were combined and were supplied with free text to enhance their sensitivity; however, they were also manually retrieved references from related research to ensure the inclusion of other studies. There were no language restrictions for searching. 


\section{Inclusion and exclusion criteria}

Studies were selected in the present research if they matched the following PICOS (population, intervention, comparator, outcome, study design) criteria: (I) Population, patients had received TKR; (II) Intervention, patients received musical interventions (music medicine or music therapy) intra-operatively, pre-operatively, or postoperatively; (III) Comparator, patients received an active treatment or control treatment (e.g., placebo, standard care, or no treatment); (IV) Outcomes such as assessment of pain severity during perioperative period, degree of anxiety, range of motion of the knee, physiological data including oxygen saturation, blood pressure, heart rate, heart rate variability, and respiratory rate; (V) Study design, RCTs.

The following conditions were considered exclusion criteria: revision knee arthroplasty; articles involving bilateral TKR; non-randomized trials; review articles; quasi-randomized trials; and articles with insufficient outcome data. The data were submitted to a third author for any divarication.

\section{Primary and secondary outcomes}

This study only gathered statistical outcomes during the perioperative period. The primary outcomes included pain severity, while secondary outcomes included degree of anxiety, average increase in CPM angles, and physiological parameters including oxygen saturation, blood pressure, heart rate, LF/HF (heart rate variability) and respiratory rate.

\section{Data extraction}

Final variables extracted included year of intervention, first author, country of origin, intervention time (perioperative, pre-operative, intra-operative, post-operative, or their combinations), type of music selection, music tracks, methodological characteristics, intervention details, participant characteristics, and measured outcomes. Two researchers independently extracted the data mentioned above. Discrepancies were discussed and resolved by additional authors. The corresponding authors of the primary studies were contacted to ensure that the integrated information was available. If there were multiple comparisons, only the interest data and information reported were extracted from the original studies.

\section{Quality assessment and risk of bias}

Two authors independently evaluated the methodological quality according to Cochrane Handbook, version 5.1.0, for Systematic Reviews of Interventions (http:// handbook.cochrane.org/). There were seven items to be included: (a) selection bias, random sequence generation; (b) selection bias, allocation concealment; (c) performance bias, blinding of the participants and personnel; (d) detection bias, blinding of outcome assessments; (e) reporting bias, selective reporting; (f) attrition bias, incomplete outcome data; (g) other biases. The entire methodological quality of each study in our review was measured as "yes" (low risk of bias), "unclear" (unclear risk of bias), or "no" (high risk of bias) and was used to obtain the risk of the bias graph and bias summary via Review Manager 5 (RevMan 5, version 5.30 Cochrane Collaboration, Oxford, UK). Any divided opinions were solved through team consensus.

\section{Statistical analysis}

Review Manager 5 (RevMan 5) software (version 5.30, Cochrane Collaboration, Oxford, UK) was adopted for the statistical analysis in the present meta-analysis, where $P$ value $<0.05$ was considered to be statistically significant. Dichotomous outcomes were shown by risk difference (RD) and 95\% confidence intervals (CIs). Continuous outcomes were shown by mean differences (MDs) and 95\% CI, which was used for evaluation based on the $P$ value and $I^{2}$ value by the standard $X^{2}$ test. When the $I^{2}<50 \%$ or $\chi^{2}$ test $>0.1$, manifesting significant heterogeneity, the fixed-effects model was adopted in the meta-analysis. Otherwise, the random-effects model was used. Sensitivity analysis was performed, if possible, to ascertain the origins of any heterogeneity.

\section{Results}

Study selection and characteristics of the selected studies In total, 172 studies were initially identified via electronic databases. Among the excluded articles, participators of three studies $[37,38]$ had both TKR and THA, and data in a particular study [39] had published in their anterior article [40]. Therefore, feasible data was unable to be acquired [41, 42]. After assessing the titles or abstracts, and after screening the full-texts of related studies, 8 RCTs satisfied the inclusion criteria [40, 43-49]. The present literature search was expounded by the PRISMA flow diagram (Fig. 1). All included articles were published between 2008 and 2019, and 555 participants were included in the analysis. The sample sizes of each study ranged from 32 to 117 . The general characteristics of RCTs included in the meta-analysis are shown in Table 1, and the study clinic intervention protocol of RCTs included in the meta-analysis are put forward in Table 2.

\section{Quality assessment and risk of bias}

The present study was evaluated according to the Cochrane Handbook for Systematic Reviews of Interventions in terms of the methodological quality of all included RCTs. Five RCTs [43-45, 47, 48] mentioned the sequence generation (randomization scheme performed) fairly well, and six trials mentioned allocation concealment [40, 43- 


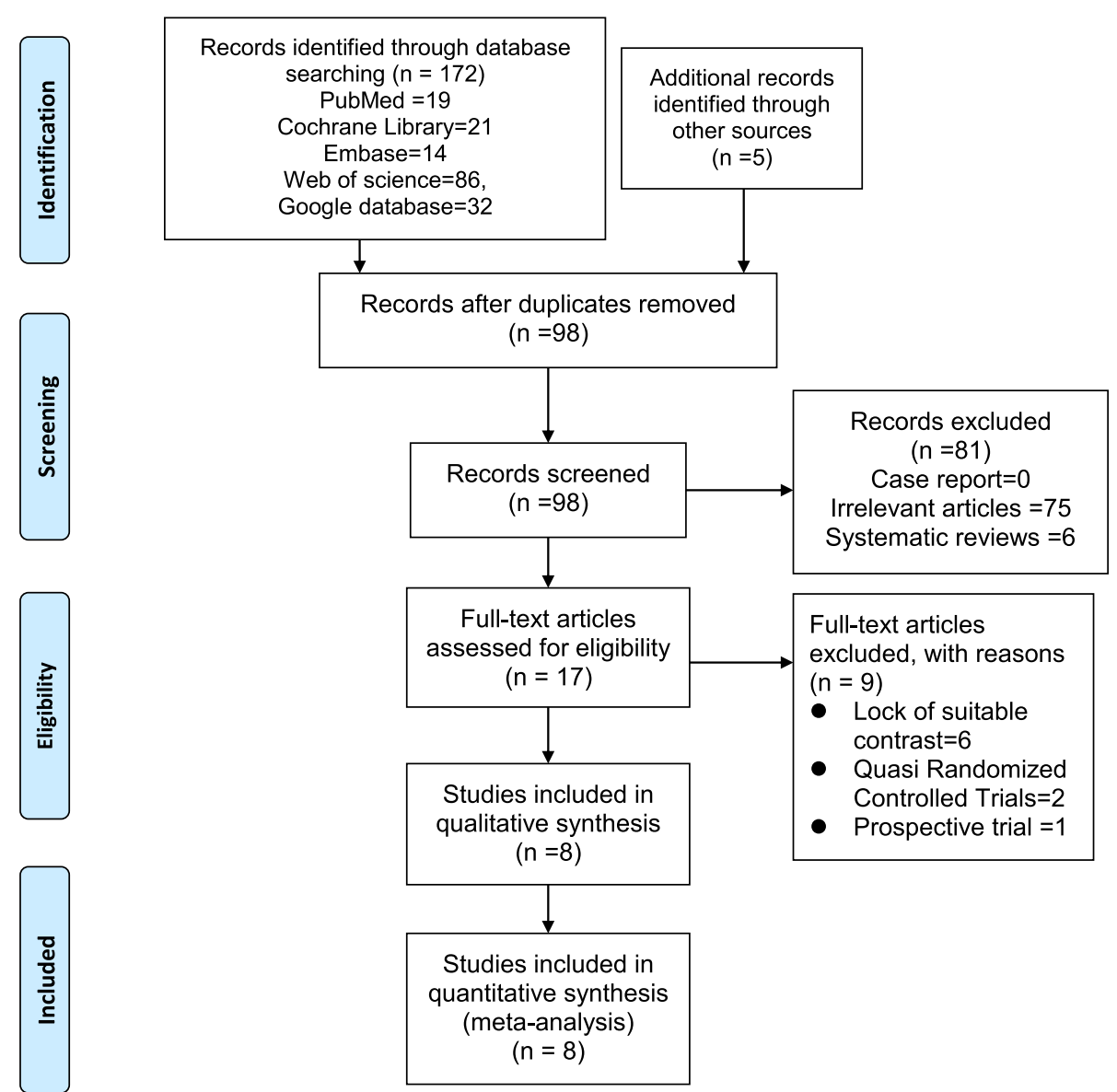

Fig. 1 The PRISMA flow diagram detailing our literature search

$45,47,48]$. In the remaining articles, this information was indistinct or absent $[46,49]$. Blinding of personnel and participants was mentioned in two trials $[46,49]$, but was not performed in six trials [40,43,44, 46-48]. In regard to outcome assessors, two trials were blinded [44, 48], though three trials were unclear [40,43, 49]. Blinding was not performed in the other three studies [45-47]. Furthermore, no other apparent bias was found in each included study. All included RCTs were considered to be low risk for attrition bias and furnished complete data. The detailed risks of bias for the eligible studies are shown in Figs. 2 and 3.

\section{Primary outcomes}

\section{Meta-analysis of pain severity}

A total of 373 patients reported pain severity in 6 studies. Two studies assessing 80 knees involved pain of VAS in the postoperative recovery room. Moreover, no significant difference was evident between the music and control groups $(\mathrm{MD}=-1.22 ; 95 \% \mathrm{CI} ;-3.38$ to $0.94 ; P$ $=0.27$ ). Only 2 studies (80 patients) reported pain of VAS back to the ward after surgery, where no significant difference was found between the music and control groups $(\mathrm{MD}=-0.61 ; 95 \% \mathrm{CI} ;-2.91$ to $1.68 ; P=0.60)$. Additionally, 5 studies (213 patients) stated related pain in the VAS score on the postoperative day (POD) 1 . The pooled data showed no significant difference between the two groups $(\mathrm{MD}=-0.28 ; 95 \% \mathrm{CI} ;-1.60$ to $1.04 ; P$ $=0.68$ ). In terms of the high heterogeneity of the three subgroups following, during postoperative recovery $\left(\chi^{2}=\right.$ 6.51; $\left.\mathrm{df}=1 ; P=0.01 ; I^{2}=85 \%\right)$; back to the ward $\left(\chi^{2}=\right.$ 6.86; $\left.\mathrm{df}=1 ; P=0.009 ; I^{2}=85 \%\right)$, POD1 $\left(\chi^{2}=19.23 ; \mathrm{df}=\right.$ 2; $P=0.0007 ; I^{2}=79 \%$ ), a random-effects model was used (Fig. 4 and Table 3).

\section{Secondary outcomes Meta-analysis of anxiety degree}

Only 2 studies (147 patients) reported the anxiety degree of VAS scores before PT on POD1. No significant difference was found between the two groups $(\mathrm{MD}=-0.18$; $95 \% \mathrm{CI} ;-2.35$ to $1.99 ; P=0.87)$. The anxiety degree of VAS scores after PT on POD1 was reported in tow of the included studies, and a total of 147 patients were involved in the meta-analysis. The pooled data showed no 
Table 1 General characteristics of RCTs included in the meta-analysis

\begin{tabular}{|c|c|c|c|c|c|c|c|c|c|c|c|c|c|c|}
\hline \multirow{3}{*}{$\begin{array}{l}\text { Studies } \\
\\
\text { Allred et al. } \\
{[37]}\end{array}$} & \multirow{3}{*}{$\begin{array}{l}\text { Year } \\
2010\end{array}$} & \multirow{3}{*}{$\begin{array}{l}\text { Country } \\
\text { USA }\end{array}$} & \multirow{3}{*}{$\begin{array}{l}\text { Type } \\
\text { RCT }\end{array}$} & \multirow{3}{*}{$\begin{array}{l}\begin{array}{l}\text { Date of } \\
\text { study }\end{array} \\
\ln 2007\end{array}$} & \multicolumn{2}{|c|}{ Sample size } & \multicolumn{4}{|c|}{ Gender } & \multicolumn{2}{|c|}{ Mean age } & \multirow{2}{*}{$\begin{array}{l}\text { Timing of } \\
\text { intervention }\end{array}$} & \multirow{2}{*}{$\begin{array}{l}\text { Primary results of } \\
\text { statistics }\end{array}$} \\
\hline & & & & & \multirow{2}{*}{$\begin{array}{l}\text { Music } \\
28\end{array}$} & \multirow{2}{*}{$\begin{array}{l}\text { Control } \\
28\end{array}$} & \multicolumn{2}{|c|}{$\begin{array}{l}\text { Music } \\
\text { (F/M) }\end{array}$} & \multicolumn{2}{|c|}{$\begin{array}{l}\text { Control } \\
\text { (F/M) }\end{array}$} & \multirow{2}{*}{$\begin{array}{l}\begin{array}{l}\text { Music } \\
(M \pm D)\end{array} \\
64.3 \pm \\
9.6\end{array}$} & \multirow{2}{*}{$\begin{array}{l}\text { Control(M } \\
\pm \mathrm{D}) \\
63.5 \pm 9.6\end{array}$} & & \\
\hline & & & & & & & 14 & 14 & 17 & 11 & & & Post-op & $\begin{array}{l}\text { I. Pain: VAS and } \\
\text { MPQ-SF } \\
\text { II. Anxiety: VAS } \\
\text { III. Physiologic data }\end{array}$ \\
\hline $\begin{array}{l}\text { Chen et al. } \\
\text { [38] }\end{array}$ & 2015 & Taiwan & $\mathrm{RCT}$ & Not reported & 30 & 30 & 20 & 10 & 25 & 5 & $\begin{array}{l}69.86 \pm \\
7.56^{\mathrm{b}}\end{array}$ & $\begin{array}{l}69.86 \pm \\
7.56^{\mathrm{b}}\end{array}$ & $\begin{array}{l}\text { Pre-op and } \\
\text { post-op }\end{array}$ & $\begin{array}{l}\text { I. Pain: VAS } \\
\text { II. Physiological } \\
\text { data III. Total } \\
\text { amount of opioids } \\
\text { used }\end{array}$ \\
\hline $\begin{array}{l}\text { Finlay et al. } \\
\text { [39] }\end{array}$ & 2016 & UK & RCT & Not reported & $72^{\mathrm{a}}$ & 17 & NS & NS & NS & NS & $\begin{array}{l}68.07 \pm \\
8.03^{b}\end{array}$ & $\begin{array}{l}68.07 \pm \\
8.03^{\mathrm{b}}\end{array}$ & $\begin{array}{l}\text { Pre-op and } \\
\text { post-op }\end{array}$ & $\begin{array}{l}\text { I. Pain: VRS/NRS } \\
\text { II. Salivary cortisol } \\
\text { concentrations } \\
\text { III. Mood states: } \\
\text { TMD }\end{array}$ \\
\hline $\begin{array}{l}\text { Hooks et al. } \\
\text { [40] }\end{array}$ & 2014 & USA & $\mathrm{RCT}$ & $\begin{array}{l}\text { September } \\
2013 \text { to } \\
\text { November } \\
2013\end{array}$ & 30 & 30 & NS & NS & NS & NS & $\begin{array}{l}66.84 \pm \\
66^{\mathrm{b}}\end{array}$ & $\begin{array}{l}66.84 \pm \\
66^{\mathrm{b}}\end{array}$ & Post-op & $\begin{array}{l}\text { I. Pain: NRS } \\
\text { II. Physiological } \\
\text { data III. Amount of } \\
\text { opioids IV. LOS }\end{array}$ \\
\hline $\begin{array}{l}\text { Hsu et al. } \\
{[41]}\end{array}$ & 2015 & Taiwan & $\mathrm{RCT}$ & $\begin{array}{l}\text { November } \\
2013 \text { to April } \\
2014\end{array}$ & 49 & 42 & 34 & 15 & 33 & 9 & $\begin{array}{l}73.9 \pm \\
7.5\end{array}$ & $\begin{array}{l}71.33 \pm \\
8.45\end{array}$ & Post-op & $\begin{array}{l}\text { I. Anxiety: VAS } \\
\text { II. Physiological } \\
\text { Parameters } \\
\text { III. CPM angles } \\
\text { 4.ROM }\end{array}$ \\
\hline $\begin{array}{l}\text { Leonard } \\
\text { et al. [42] }\end{array}$ & 2019 & USA & $\mathrm{RCT}$ & Not reported & 16 & 16 & 11 & 5 & 12 & 4 & $\begin{array}{l}67.9(45- \\
87)^{c}\end{array}$ & $\begin{array}{l}67.6(53- \\
80)^{c}\end{array}$ & Post-op & I. Pain: NRS \\
\hline $\begin{array}{l}\text { Simcock } \\
\text { et al. [43] }\end{array}$ & 2008 & USA & RCT & $\begin{array}{l}\text { Junr } 2006 \text { to } \\
\text { March } 2007\end{array}$ & 60 & 57 & 37 & 23 & 33 & 24 & $\begin{array}{l}31.3 \pm \\
5.8\end{array}$ & $29.6 \pm 6.1$ & Intra-op & $\begin{array}{l}\text { I. Satisfaction scores } \\
\text { II. Pain: VAS }\end{array}$ \\
\hline $\begin{array}{l}\text { You et al. } \\
{[44]}\end{array}$ & 2019 & China & $\mathrm{RCT}$ & $\begin{array}{l}\text { June } 2018 \text { to } \\
\text { June } 2018\end{array}$ & 25 & 25 & NS & NS & NS & NS & $\begin{array}{l}65.2 \pm \\
3.6^{\mathrm{b}}\end{array}$ & $65.2 \pm 3.6^{b}$ & Post-op & $\begin{array}{l}\text { I. Physiological } \\
\text { Parameters } \\
\text { II. CPM angles } \\
\text { III. ROM }\end{array}$ \\
\hline
\end{tabular}

NS not stated, $R C T$ randomized controlled trial, F/M female/male, $M \pm D$ means \pm standard deviation, Post-op = postoperative, pre-op preoperative, Intra-op intraoperative, VAS visual analog scale, NRS numerical rating scale, MPQ-SF McGill pain questionnaire short-form, TMD total mood disturbance, LOS length of stay, $C P M$ continuous passive motion, $P P I$ present pain intensity, $P R I$ pain rating intensity, ROM range of motion

${ }^{\text {a }}$ Containing four experimental groups

${ }^{\mathrm{b}}$ The age of music group and control group

cAge range

significant difference between the music and control groups $(\mathrm{MD}=-1.49 ; 95 \% \mathrm{CI} ;-3.78$ to $0.79 ; P=0.20)$. Finding the high heterogeneity in before PT $\left(\chi^{2}=8.20\right.$; $\left.\mathrm{df}=1 ; P=0.004 ; I^{2}=88 \%\right)$ and after PT $\left(\chi^{2}=10.86 ; \mathrm{df}\right.$ $=1 ; P=0.001 ; I^{2}=91 \%$ ), a random-effects model was adopted (Fig. 5 and Table 3).

\section{Meta-analysis of the average increase in CPM angles}

A total of 141 patients reported an average increase in CPM angles in tow studies on POD1. There were significant differences between the music and control groups (MD $=8.90 ; 95 \% \mathrm{CI} ; 3.72$ to $14.08 ; P=0.0008)$. Two studies assessing 141 knees involved an average increase in CPM angles POD2, and a significant difference was observed between the included studies $(\mathrm{MD}=4.24,95 \%$ CI 215 to $6.32, P<0.00001)$. In view of the high heterogeneity in the tow subgroups, POD1 $\left(\chi^{2}=6.21\right.$; $\mathrm{df}=1$;
$\left.P=0.01 ; I^{2}=84 \%\right)$ and POD2 $(\chi 2=3.99 ; \mathrm{df}=1 ; P=$ $\left.0.13 ; I^{2}=56 \%\right)$, a random-effects model was utilized (Fig. 6 and Table 3).

\section{Meta-analysis of heart rate}

Heart rate before PT on postoperative day (POD) 1 was reported in two studies, where a total of 147 patients was involved in the present research. The pooled data showed no significant difference between the two methods of interventions $(\mathrm{MD}=-1.23,95 \% \mathrm{CI}-2.66$ to $5.13, P=0.54)$. Three trails (207 patients) reported the heart rate after PT on postoperative day (POD) 1. The pooled data showed no significant difference $(\mathrm{MD}=$ - $0.06,95 \% \mathrm{CI}-3.53$ to $3.65, P=0.97$ ) between the two methods of interventions. Due to the important heterogeneity in heart rate before PT on POD $1\left(\chi^{2}=0.49\right.$; df $\left.=1 ; P=0.49 ; I^{2}=0 \%\right)$ and heart rate after PT on POD 1 
Table 2 Clinic intervention protocol of RCTs included in the meta-analysis

\begin{tabular}{|c|c|c|c|c|c|c|}
\hline Studies & $\begin{array}{l}\text { Intervention } \\
\text { details }\end{array}$ & $\begin{array}{l}\text { Intervention } \\
\text { and } \\
\text { comparison }\end{array}$ & Type of music & Follow-up assessments & Intervention treatment & $\begin{array}{l}\text { Control } \\
\text { treatment }\end{array}$ \\
\hline Allred et al. & $\begin{array}{l}\text { Music via } \\
\text { headphones }\end{array}$ & $\begin{array}{l}\text { Music vs. } \\
\text { quiet rest } \\
\text { period }\end{array}$ & Easy listening & $\begin{array}{l}\mathrm{D} 1: \mathrm{T} 1=20 \text { min before first } \mathrm{PT} \\
\text { session; } \mathrm{T} 2=\text { just before } \mathrm{PT} ; \mathrm{T} 3 \\
=\text { immediately after PT, } \mathrm{T} 4= \\
20 \text { min after } \mathrm{PT} ; \mathrm{T} 5=6 \text { hours } \\
\text { after intervention. }\end{array}$ & $\begin{array}{l}\text { Listening to CD of easy } \\
\text { listening music on } \\
\text { headphones } 20 \text { min before } \\
\text { first ambulation and for } 20 \\
\text { min rest period after } \\
\text { ambulation. Music had no } \\
\text { lyrics, } 60-80 \text { beats } / \mathrm{min} \text {. }\end{array}$ & $\begin{array}{l}20 \text { min quiet rest } \\
\text { period }\end{array}$ \\
\hline Chen et al. & $\begin{array}{l}\text { Music via } \\
\text { broadcast } \\
\text { speakers }\end{array}$ & $\begin{array}{l}\text { Music vs. } \\
\text { standard care }\end{array}$ & $\begin{array}{l}\text { Soothing piano } \\
\text { and violin }\end{array}$ & $\begin{array}{l}\text { I. } 10 \text { min while the } \\
\text { investigator prepared the } \\
\text { study equipment at rest. } \\
\text { II. In the surgical room in the } \\
\text { morning. III. In the } \\
\text { postoperative recovery area } \\
\text { after the surgery. } \\
\text { IV. Sending back to the ward } \\
\text { One hour later. }\end{array}$ & $\begin{array}{l}\text { Soothing piano and Chinese } \\
\text { violin music played on a CD } \\
\text { player through broadcast } \\
\text { speakers. Played for } 30 \text { min in } \\
\text { the preoperative ward, } 30 \text { min } \\
\text { in the surgical room waiting } \\
\text { area and } 1 \mathrm{~h} \text { in postoperative } \\
\text { recovery. }\end{array}$ & Usual care \\
\hline Finlay et al. & $\begin{array}{l}\text { Music via } \\
\text { headphones }\end{array}$ & $\begin{array}{l}\text { Music vs. } \\
\text { quiet bed } \\
\text { rest }\end{array}$ & $\begin{array}{l}\text { Varying degrees } \\
\text { of harmonicity } \\
\text { and rhythmicity }\end{array}$ & $\begin{array}{l}\text { Pre-operative assessment at } \\
\text { pre-admissions } 2 \text { weeks. All as- } \\
\text { sessment measures were com- } \\
\text { pleted (D1-3) each day post- } \\
\text { surgery. PCA usage was moni- } \\
\text { tored pre-intervention in the } \\
\text { immediate } 24 \text { h post- } \\
\text { operatively (D0). }\end{array}$ & $\begin{array}{l}\text { Four music-listening groups } \\
\text { with four music types. Being } \\
\text { visited daily and completing } \\
\text { pre- and post-test at the same } \\
\text { time each day, once per day } \\
\text { for } 3 \text { days after surgery }\end{array}$ & $\begin{array}{l}\text { Wearing noise } \\
\text { canceling } \\
\text { headphones with } \\
\text { no input }\end{array}$ \\
\hline Hooks et al. & $\begin{array}{l}\text { Music via } \\
\text { headphones }\end{array}$ & $\begin{array}{l}\text { Music vs. } \\
\text { quiet bed } \\
\text { rest }\end{array}$ & $\begin{array}{l}\text { Soft rock, jazz, } \\
\text { Easy listening, } \\
\text { R\&B, Classical, } \\
\text { Bluegrass, } \\
\text { Country, Gospel, } \\
\text { Pop, Nature } \\
\text { sound }\end{array}$ & $\begin{array}{l}\text { The patients were monitored } \\
\text { in the morning between the } \\
\text { times of 10:00 AM to 12:00 } \\
\text { PM, early afternoon between } \\
\text { 2:00 PM to 5:00 PM and } \\
\text { evening between 7:30 PM to } \\
\text { 9:30 PM on the first day after } \\
\text { surgery. }\end{array}$ & $\begin{array}{l}\text { The patients were asked not } \\
\text { to alter the music player at } \\
\text { any time. Before each session } \\
\text { with the patients, I checked } \\
\text { with the nurse and physical } \\
\text { therapist to make sure the } 30 \text { - } \\
\text { min session would not inter- } \\
\text { fere with the patient's care } \\
\text { plan. }\end{array}$ & $\begin{array}{l}\text { wearing the ear } \\
\text { buds for } 30 \text { min } \\
\text { without music and } \\
\text { the individual } \\
\text { patient room door } \\
\text { closed }\end{array}$ \\
\hline Hsu et al. & $\begin{array}{l}\text { Music via } \\
\text { headphones }\end{array}$ & $\begin{array}{l}\text { Music vs. } \\
\text { standard care }\end{array}$ & $\begin{array}{l}\text { Relaxing slow } \\
\text { tempo, low tone, } \\
\text { and soft melody }\end{array}$ & $\begin{array}{l}\text { Receiving CPM rehabilitation } \\
\text { twice daily ( } 10 \text { AM and } 4 \text { PM) } \\
\text { on the first and second day } \\
\text { following surgery }\end{array}$ & $\begin{array}{l}\text { Listening to music from } 10 \\
\text { min before receiving CPM } \\
\text { until the end of the session } \\
\text { ( } 25 \text { min in total) on the first } \\
\text { and second day following } \\
\text { surgery }\end{array}$ & $\begin{array}{l}\text { Only to rest in bed } \\
10 \text { min before } \\
\text { CPM. }\end{array}$ \\
\hline $\begin{array}{l}\text { Leonard et } \\
\text { al }\end{array}$ & $\begin{array}{l}\text { Music via } \\
\text { music } \\
\text { therapist }\end{array}$ & $\begin{array}{l}\text { Music vs. } \\
\text { standard care }\end{array}$ & $\begin{array}{l}\text { Rock, Country, } \\
\text { Traditional, Pop, } \\
\text { Pop, Jazz, Bossa } \\
\text { Nova }\end{array}$ & $\begin{array}{l}\text { Baseline ( } 1 \text { min after flexion } \\
\text { assessment), after each } 2 \text { min } \\
\text { intervention period (two } \\
\text { periods). }\end{array}$ & $\begin{array}{l}\text { Music therapy during } \\
\text { bicycling pedaling exercise } \\
\text { postoperatively. Live music } \\
\text { was played by a music } \\
\text { therapist during PT supported } \\
\text { pedaling exercise for } 2 \text { min, } \\
\text { then pedaling alone with no } \\
\text { music. Music included singing } \\
\text { with paced guitar } \\
\text { accompaniment and at a } \\
\text { moderate/fast tempo. }\end{array}$ & $\begin{array}{l}\text { Pedaling exercise } \\
\text { with no music. }\end{array}$ \\
\hline $\begin{array}{l}\text { Simcock } \\
\text { et al. }\end{array}$ & $\begin{array}{l}\text { Music via } \\
\text { headphones }\end{array}$ & $\begin{array}{l}\text { Music vs. } \\
\text { placebo }\end{array}$ & $\begin{array}{l}\text { Patient's choice } \\
\text { what they like }\end{array}$ & $\begin{array}{l}\text { Baseline, } 3 \mathrm{~h}, 6 \mathrm{~h} \text {, and } 24 \mathrm{~h} \\
\text { after surgery procedure }\end{array}$ & $\begin{array}{l}\text { Patient selection music during } \\
\text { surgery by wearing } \\
\text { headphones. }\end{array}$ & $\begin{array}{l}\text { White noise } \\
\text { control on } \\
\text { headphones. }\end{array}$ \\
\hline You et al. & $\begin{array}{l}\text { Music via } \\
\text { headphones }\end{array}$ & $\begin{array}{l}\text { Music vs. } \\
\text { quiet rest } \\
\text { period }\end{array}$ & Soothing music & $\begin{array}{l}\text { Preoperative, the first day and } \\
\text { the second day after surgery } \\
\text { during CPM }\end{array}$ & $\begin{array}{l}\text { Starting CPM and listening to } \\
\text { music until the end of the first } \\
10 \text { min during surgery by } \\
\text { wearing headphones. }\end{array}$ & Usual care \\
\hline
\end{tabular}

$D$ postoperative day, $P T$ physical therapy, CPM continuous passive motion 


\section{Random sequence generation (selection bias)}

Allocation concealment (selection bias)

Blinding of participants and personnel (performance bias)

Blinding of outcome assessment (detection bias)

Incomplete outcome data (attrition bias)

Selective reporting (reporting bias)

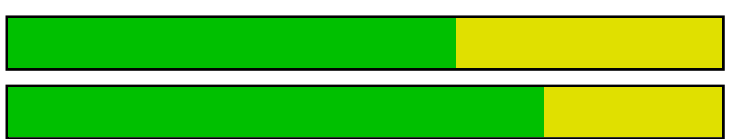

Other bias
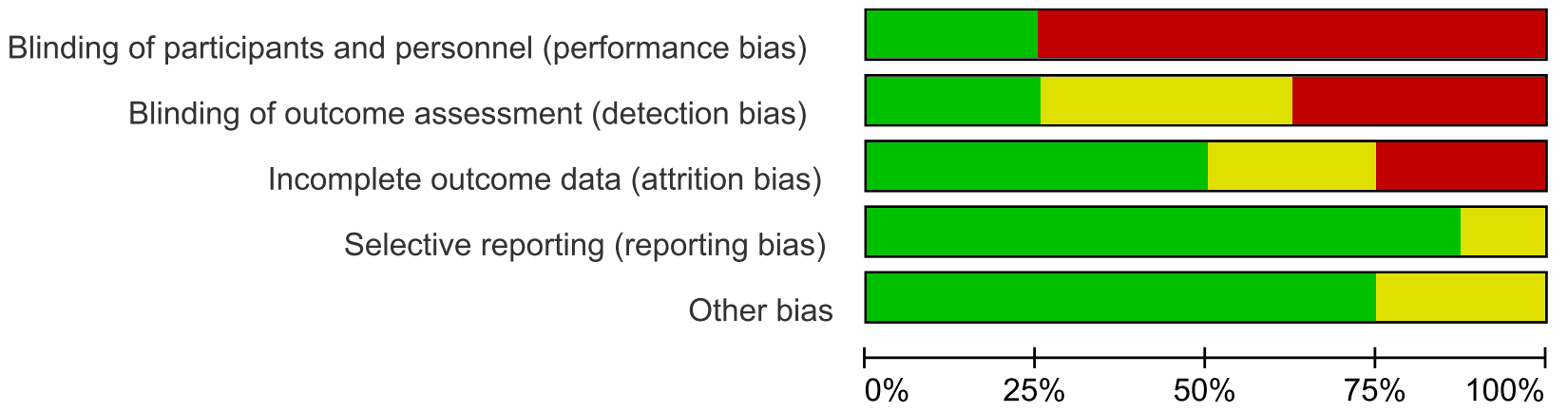

\section{Low risk of bias}

Unclear risk of bias

High risk of bias

Fig. 2 The risk of bias summary of the included studies. (+ represents yes; - represents no; ? represents not clear)

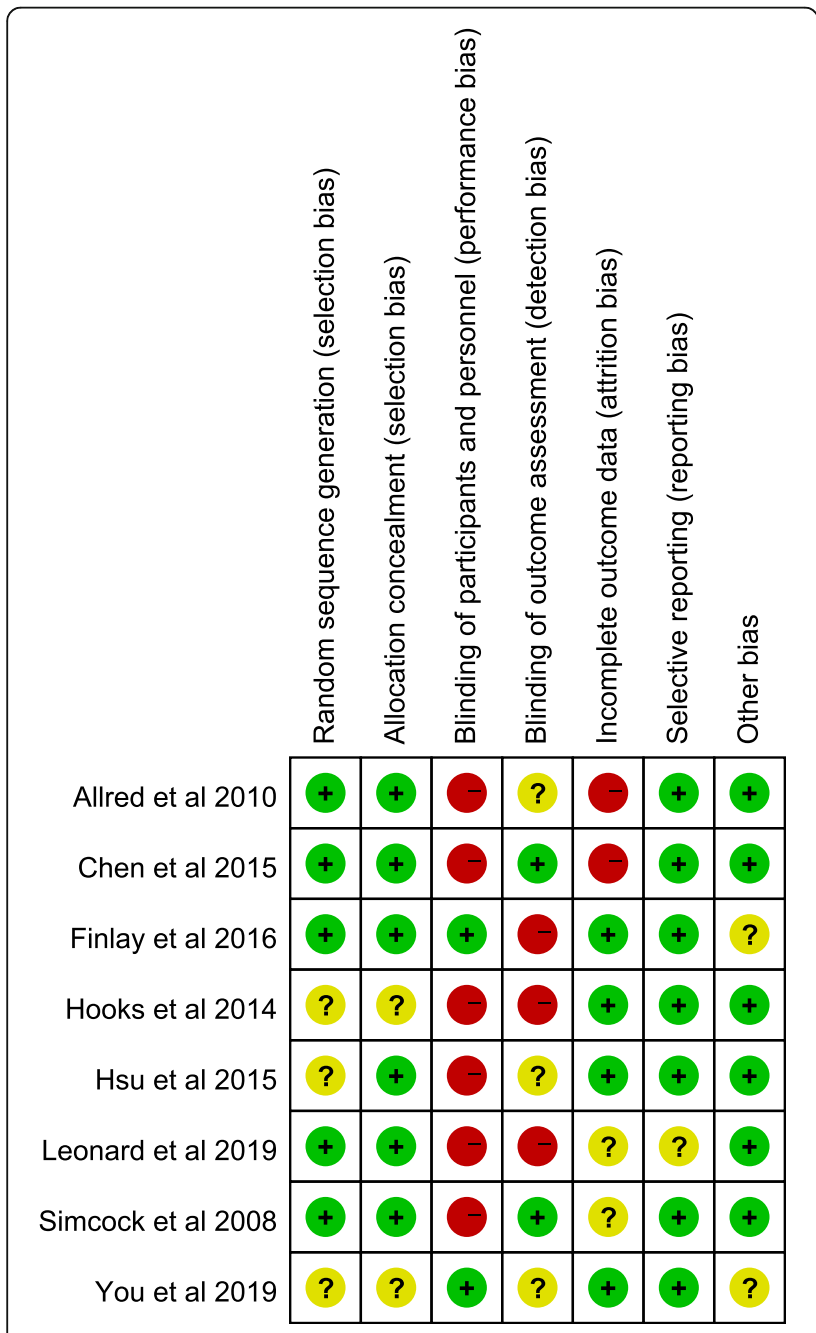

Fig. 3 The risk of bias graph of the included studies. $\left(\chi^{2}=2.37 ; \mathrm{df}=2 ; P=0.31 ; I^{2}=16 \%\right)$, a fixed-effects model was applied (Fig. 7 and Table 3 ).

\section{Meta-analysis of blood pressure}

Two studies comprised of 90 patients reported systolic blood pressure, showing no statistical significance between the music and control groups $(\mathrm{MD}=-2.76,95 \%$ CI -11.10 to $5.58, P=0.52)$. The data of diastolic blood pressure was reported by two trails (147 patients). No significant difference was found between the two groups $(\mathrm{MD}=-1.80,95 \% \mathrm{CI}-5.78$ to $2.19, P=0.38) . \mathrm{A}$ random-effects model was used due to significant heterogeneity, systolic blood pressure $\left(\chi^{2}=0.54\right.$; $\mathrm{df}=1 ; P=$ $\left.0.46 ; I^{2}=0 \%\right)$, and diastolic blood pressure $\left(\chi^{2}=0.05\right.$; $\mathrm{df}$ $=2 ; P=1 ; I^{2}=0 \%$ ), which was found in the data of blood pressure (Fig. 8 and Table 3).

\section{Meta-analysis of respiratory rate}

Only 2 studies (116 patients) reported the respiratory rate after PT on POD1. No significant difference was found between the two groups $(\mathrm{MD}=0.14 ; 95 \% \mathrm{CI}-$ 0.33 to $0.61 ; P=0.56)$. A fixed-effects model was used as significant heterogeneity was found in the data of respiratory rate $\left(\chi^{2}=0.01 ; \mathrm{df}=1 ; P=0.93 ; I^{2}=0 \%\right.$ ) (Fig. 9 and Table 3).

\section{Meta-analysis of oxygen saturation}

Oxygen saturation was reported in two studies, where a total of 116 knees were involved in the meta-analysis. There was no significant difference between the music and control groups $(\mathrm{MD}=-0.51 ; 95 \% \mathrm{CI}-1.32$ to $0.31 ; P=0.22)$. In view of low heterogeneity $\left(\chi^{2}=0.45\right.$; df $\left.=1 ; P=0.50 ; I^{2}=0 \%\right)$, a fixed-effects model was applied (Fig 10 and Table 3). 


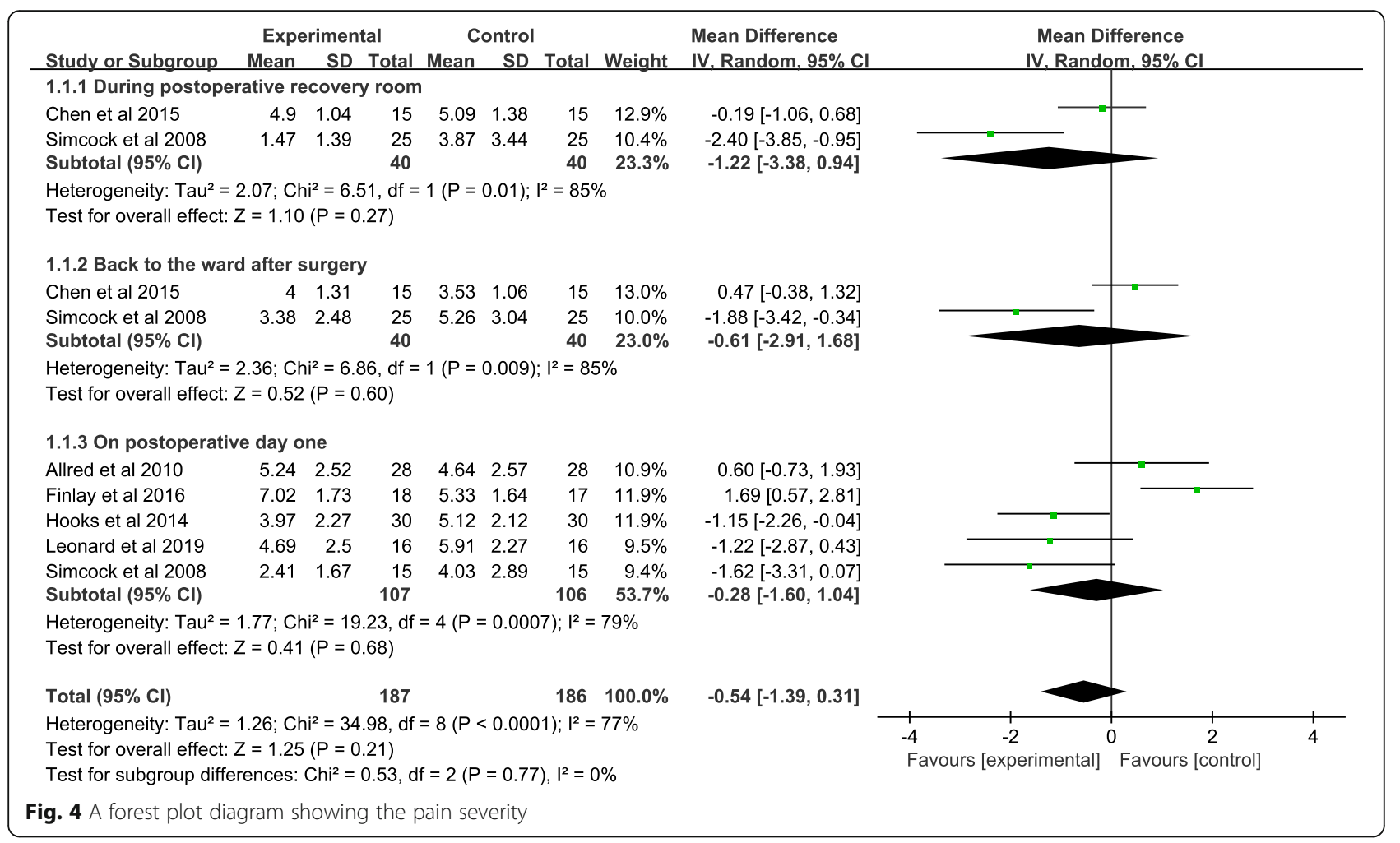

\section{Meta-analysis of LF/HF ratio}

Two studies (141 patients) reported the LF/HF ratio before PT on POD 1, and a significant difference was shown between the included studies $(\mathrm{MD}=-1.00$, 95\% CI 1.23 to $-0.78, P<0.001)$. Two studies with 141 patients reported the LF/HF after PT on POD1, demonstrating a statistical significance between the music and control groups $(\mathrm{MD}=-1.40,95 \% \mathrm{CI}-1.50$ to $-0.30, P<0.001)$. Data pertaining to LF/HF before PT on POD 2 was reported by two trials of 141 patients. A significant difference was found between the two groups ( $\mathrm{MD}=-0.90$, $95 \% \mathrm{CI}-0.98$ to $-0.82, P<0.001)$. Data regarding the LF/HF after PT on POD 2 was reported in two of the included studies, where a total of 141 patients were involved in the meta-analysis. The pooled data showed a significant difference between the music and control groups $(\mathrm{MD}=$ - 1.60; $95 \%$ CI -1.71 to $-1.49 ; P<0.001$ ). Low heterogeneity of the four subgroups was observed, where POD1: before $\mathrm{PT}\left(\chi^{2}=0.00 ; \mathrm{df}=1 ; P=0.98 ; I^{2}=0 \%\right)$, POD1: after $\mathrm{PT}\left(\chi^{2}=0.00 ; \mathrm{df}=1 ; P=0.98 ; I^{2}=0 \%\right)$, POD2: after $\mathrm{PT}\left(\chi^{2}\right.$ $\left.=0.00 ; \mathrm{df}=1 ; P=0.95 ; I^{2}=0 \%\right)$, POD2: before $\mathrm{PT}\left(\chi^{2}=\right.$ 0.00 ; $\mathrm{df}=1 ; P=1.00 ; I^{2}=0 \%$ ), a fixed-effects model was used (Fig. 11 and Table 3).

\section{Subgroup analysis of others}

A subgroup analyses were conducted to assess the effects of music via headphones as well as fast-paced music between the two groups (Table 4). The outcomes indicated that patients in the music groups had no significant difference in respiratory rate, heart rate, pain severity, oxygen saturation, and blood pressure compared to the control groups with or without music via headphones and fast-paced music.

\section{Discussion}

Recently, an increasing number of patients received TKR [50]; however, pain management remains unsatisfactory following surgery [51]. Epidural analgesia, patientcontrolled analgesia (PCA), and other medications serve as conventional methods in controlling pain [52-54], which may be associated with side effects. Multimodal analgesia implements at least two separate modalities of analgesia [55], and non-pharmacologic approaches are one aspect of multimodal therapy [56]. Music may be regarded to be very effective in terms of nonpharmacological pain management strategies [57]; however, its efficacy is known in relation to patients treated with TKR. This study is the first systematic review and meta-analysis evaluating the efficiency of musical interventions on patients treated with TKR, which attempted to determine a more reasonable and standard implementation of musical interventions.

\section{Pain severity}

In the present meta-analysis, no significant difference was observed for VAS scores during the postoperative recovery 
Table 3 Clinical results of meta-analysis

\begin{tabular}{|c|c|c|c|c|c|c|c|c|c|}
\hline \multirow[t]{2}{*}{ Clinical results } & \multirow[t]{2}{*}{ Studies } & \multicolumn{3}{|c|}{ Number of participants } & \multicolumn{5}{|l|}{ Incidence } \\
\hline & & Total & Music & $\overline{\text { Control }}$ & $P$ & MD & $95 \% \mathrm{Cl}$ & Heterogeneity $\mathrm{P}\left(I^{2}\right)$ & Model \\
\hline \multicolumn{10}{|l|}{ Pain severity } \\
\hline During PRR & 2 & 80 & 40 & 40 & 0.27 & -1.22 & -3.38 to 0.94 & $0.01(85 \%)$ & Random \\
\hline Back to the ward after surgery & 2 & 80 & 40 & 40 & 0.60 & -0.61 & -2.91 to 1.68 & $0.009(85 \%)$ & Random \\
\hline On POD 1 & 5 & 213 & 107 & 106 & 0.68 & -0.28 & -1.60 to 1.04 & $0.0007(79 \%)$ & Random \\
\hline \multicolumn{10}{|l|}{ Anxiety degree } \\
\hline Before PT on POD 1 & 2 & 147 & 77 & 70 & 0.87 & -0.18 & -2.35 to 1.99 & $0.004(88 \%)$ & Random \\
\hline After PT on POD 1 & 2 & 147 & 77 & 70 & 0.20 & -1.49 & -3.78 to 0.79 & $0.001(91 \%)$ & Random \\
\hline \multicolumn{10}{|l|}{ Average increase in CPM angles } \\
\hline On POD 1 & 2 & 141 & 74 & 67 & 0.0008 & 8.90 & 3.72 to 14.08 & $0.01(84 \%)$ & Random \\
\hline On POD 2 & 2 & 141 & 74 & 67 & $<0.00001$ & 4.24 & 2.15 to 6.32 & $0.13(56 \%)$ & Random \\
\hline \multicolumn{10}{|l|}{ Heart rate } \\
\hline Before PT on POD 1 & 2 & 147 & 77 & 70 & 0.54 & 1.23 & -2.66 to 5.13 & $0.49(0 \%)$ & Fixed \\
\hline After PT on POD 1 & 3 & 207 & 107 & 100 & 0.97 & 0.31 & -3.53 to 3.65 & $0.31(16 \%)$ & Fixed \\
\hline \multicolumn{10}{|l|}{ Blood pressure } \\
\hline Systolic blood pressure & 2 & 90 & 45 & 45 & 0.52 & -2.76 & -11.10 to 5.58 & $0.46(0 \%)$ & Fixed \\
\hline Diastolic blood pressure & 2 & 90 & 45 & 45 & 0.38 & -1.80 & -5.78 to 2.19 & $0.83(0 \%)$ & Random \\
\hline Respiratory rate & 2 & 116 & 58 & 58 & 0.56 & 0.14 & -0.33 to 0.61 & $0.93(0 \%)$ & Fixed \\
\hline Oxygen saturation & 2 & 116 & 58 & 58 & 0.22 & -0.51 & -1.32 to 0.31 & $0.50(0 \%)$ & Fixed \\
\hline \multicolumn{10}{|l|}{ LF/HF ratio } \\
\hline Before PT on POD 1 & 2 & 141 & 74 & 67 & $<0.00001$ & -1.00 & -1.23 to -0.78 & $0.96(0 \%)$ & \\
\hline After PT on POD 1 & 2 & 141 & 74 & 67 & $<0.00001$ & -1.40 & -1.50 to -1.30 & $0.98(0 \%)$ & Fixed \\
\hline Before PT on POD 2 & 2 & 141 & 74 & 67 & $<0.00001$ & -0.90 & -0.98 to -0.82 & $0.95(0 \%)$ & Fixed \\
\hline After PT on POD 2 & 2 & 141 & 74 & 67 & $<0.00001$ & -1.60 & -1.71 to -1.49 & $1.00(0 \%)$ & Fixed \\
\hline
\end{tabular}

PRR postoperative recovery room, MD mean difference, CI confidence interval, FPM fast-paced music, POD postoperative day, CPM continuous passive motion, LF/ $H F$ one kind index of heart rate variability

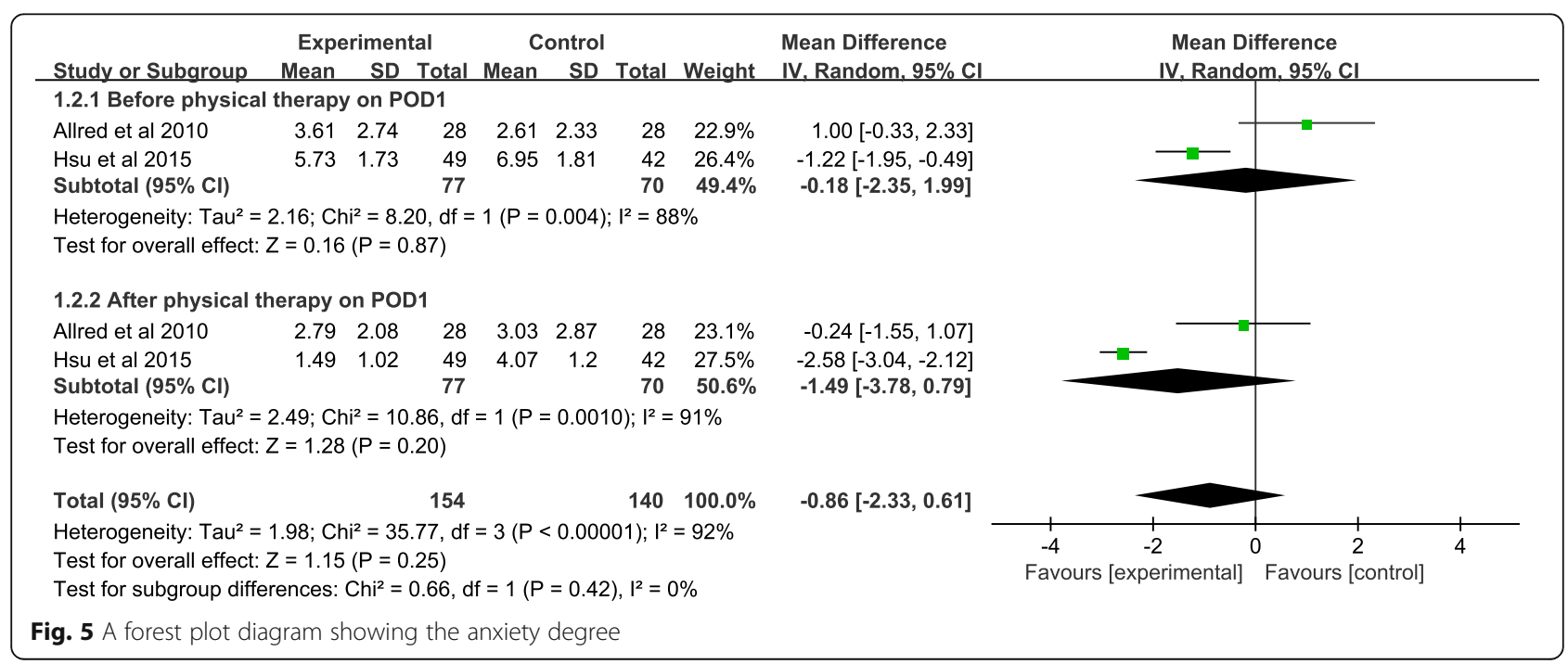




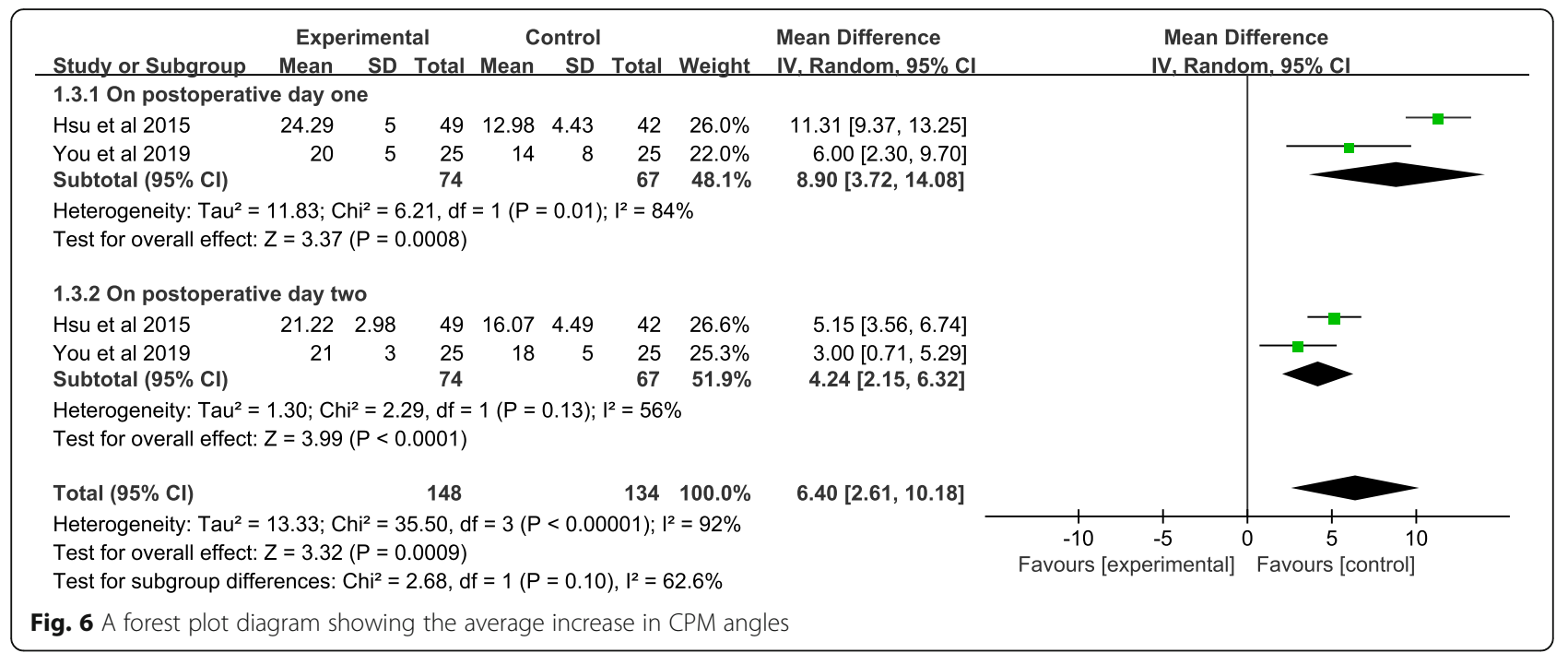

room, back to the ward after surgery, and postoperative day 1 between the music and control groups. The corresponding result is at variance with previous outcomes. First, researchers have previously shown the positive effects of musical interventions in different aspects of treatment such as cesarean section, intestinal, gynecologic, and nasal care [5861]. Orthopedic surgeries are frequently associated with different outcomes in other types of surgery. Due to copious amounts of bone destruction and soft tissue injury, orthopedic surgery is generally associated with insufferable postsurgical pain [62]. Second, one study found that musical interventions performed immediately after TKR obviously alleviated pain over time [43] and mentioned that such interventions resulted in reduced opioid dosages and incidence of adverse reactions. The best efforts were made in collecting data long after having TKR as this may make a difference to a certain degree but failed due to the limited number of RCTs. Third, musical interventions could, in theory, shift one's attention [63, 64], make people relax [65], and increase one's sense of well-being [22]. We consider the main reason why it is different from us is the increased pain due to functional exercise in order to attain better knee flexion angles, which is a key result indicator of TKR surgery [66]. This study did not exclude the possibility of being influenced by subjective factors as the VAS score is a subjective scale. In addition, the heterogeneity of musical interventions should be noted as it also leads to divergence.

\section{Anxiety degree}

Previous studies have reported postoperative decreased anxiety with intraoperative music use in orthopedic

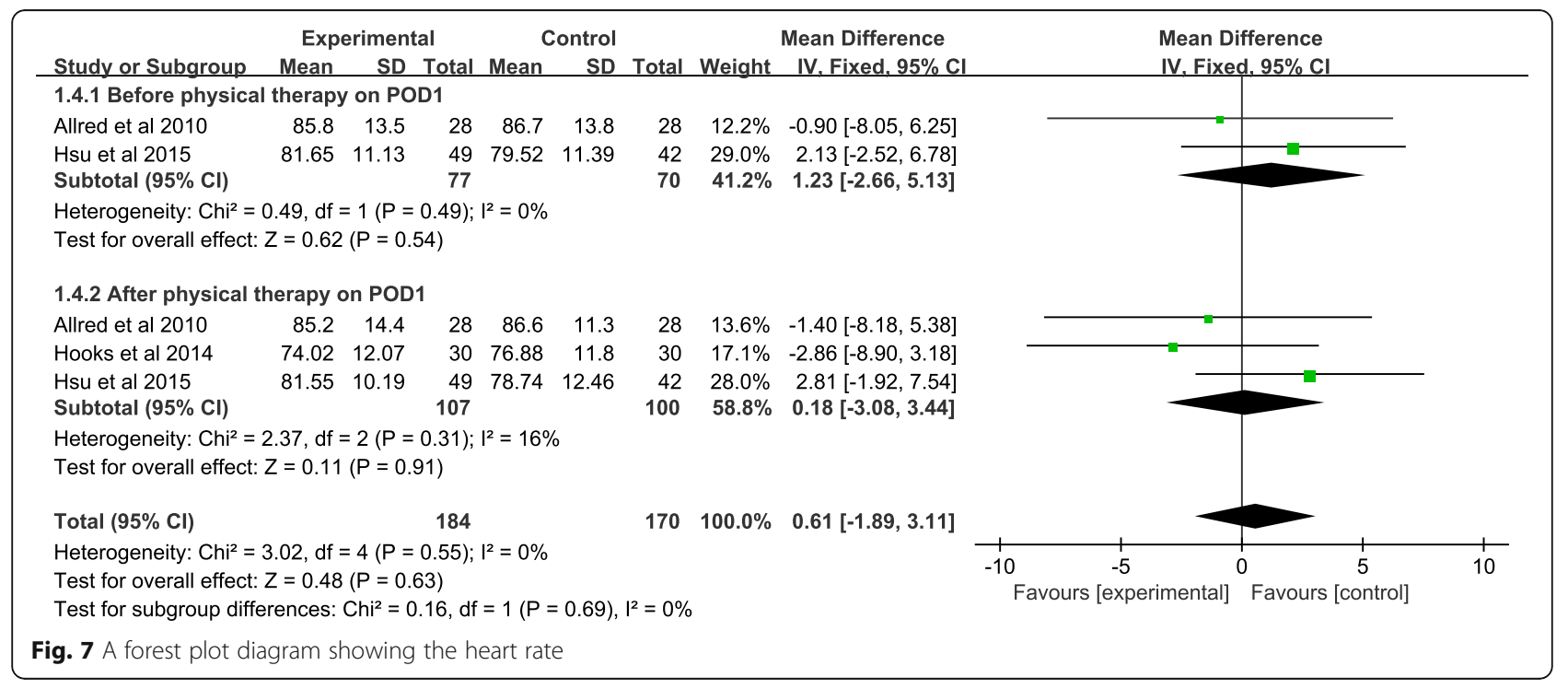




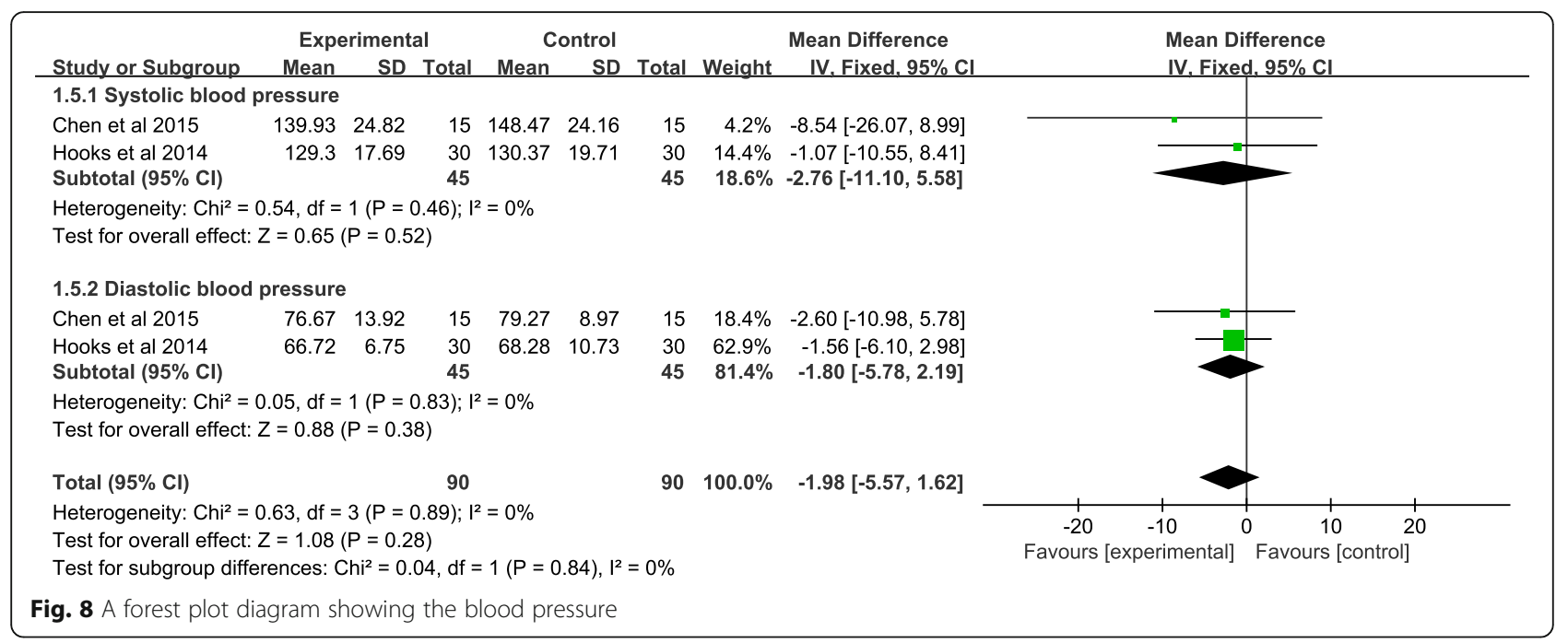

surgery [67]. Due to limited studies, the present metaanalysis only collected data regarding before and after physical therapy with postoperative music use on POD 1 . The results of the combined analysis showed that the music and control groups had no significant difference in anxiety degree after TKR. This outcome is similar to that of Allred and his colleagues [43], though another study found positive outcomes [40], which may be explained by the timing of the musical interventions. In Allred's study, they rendered their music before and after initial physical therapy. However, Hsu and his colleagues provided music in three moments: before, during and after physical therapy. Therefore, we assume whether increasing the frequency of music may be associated with a positive efficiency. A similar assumption was supported in a previous systematic review [34], but varying surgical procedures may result in unreliable evidence. As correlation studies are limited in TKR surgery, this study failed to obtain an accurate answer. In addition, it is worth noting that a sense of stress can excite or stimulate a patient's sympathetic nervous system, facilitating anxiety [68].

\section{The average increase in CPM angles}

The average increase in CPM angles was the secondary outcome assessed in this meta-analysis. Accordingly, significant differences were noted in the first and second days following surgery between the two groups. Many researchers posited that postoperative knee flexion angle is one of the main prognostic indexes of TKR surgery [69-72], and treatment of CPM was current clinical common practice [73, 74]. To this effect, CPM was reported to increase the voluntary knee joint ROM angle by an average of $4.3^{\circ}$ in a short period [70]. As CPM treatment stretches surgical wounds, patients suffered from severe pain during this process. Therefore, certain patients were unsuccessful in complying with daily CPM rehabilitation. As the feeling of fear caused their muscles to tighten, the effectiveness of CPM was impacted. Patients who are relaxed during rehabilitation would improve the effectiveness of the treatment [75]. Music is known to be an art that promotes relaxation, which theoretically make sense. However, more RCTs are needed to confirm the degree of relaxation.

\section{Physiologic parameters}

Thus far, adopting musical treatment in clinical practice remains ambiguous. In order to generate further discussion, physiological parameters serve as an important component in accessing interventions. This study collected multiple physiologic parameters including oxygen saturation, blood pressure, heart rate, LF/HF ratio, and

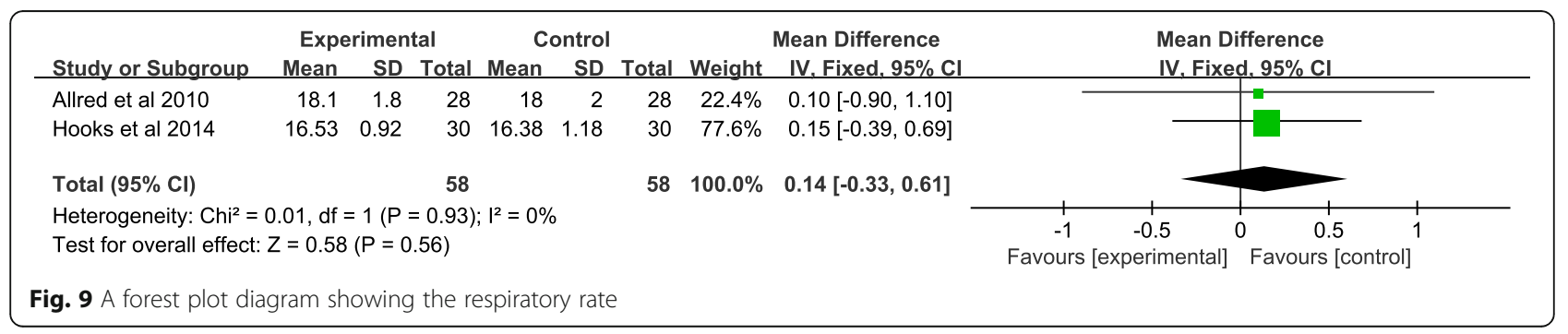




\begin{tabular}{|c|c|c|c|c|c|c|c|c|c|c|c|c|}
\hline \multirow[b]{2}{*}{ Study or Subgroup } & \multicolumn{3}{|c|}{ Experimental } & \multicolumn{2}{|c|}{ Control } & \multirow{2}{*}{ Total } & \multirow{2}{*}{\multicolumn{2}{|c|}{$\begin{array}{cc} & \text { Mean Difference } \\
\text { Weight } & \text { IV. Fixed. } 95 \% \mathrm{Cl}\end{array}$}} & \multirow{2}{*}{\multicolumn{4}{|c|}{$\begin{array}{l}\text { Mean Difference } \\
\text { IV. Fixed, } 95 \% \mathrm{Cl}\end{array}$}} \\
\hline & Mean & SD & Total & Mean & SD & & & & & & & \\
\hline Allred et al 2010 & 95.1 & 2.7 & 28 & 96 & 2.7 & 28 & $33.1 \%$ & $-0.90[-2.31,0.51]$ & & - & & \\
\hline Hooks et al 2014 & 96.23 & 1.79 & 30 & 96.54 & 2.13 & 30 & $66.9 \%$ & $-0.31[-1.31,0.69]$ & & & & \\
\hline Total $(95 \% \mathrm{Cl})$ & & & 58 & & & 58 & $100.0 \%$ & $-0.51[-1.32,0.31]$ & & & & \\
\hline $\begin{array}{l}\text { Heterogeneity: } \mathrm{Chi}^{2}= \\
\text { Test for overall effect: }\end{array}$ & $\begin{array}{l}.45, d f= \\
Z=1.22\end{array}$ & $\begin{array}{l}=1(P= \\
(P=0 .\end{array}$ & $\begin{array}{l}=0.50) ; \\
.22)\end{array}$ & $; I^{2}=0 \%$ & & & & & $\begin{array}{c}-2 \\
\text { Favours }\end{array}$ & $\begin{array}{ll}-1 & 0 \\
\text { perimental] }\end{array}$ & $\begin{array}{l}0 \\
0 \\
\text { Favours [control] }\end{array}$ & 2 \\
\hline
\end{tabular}

respiratory rate, though only LF/HF showed statistical significance. Similar results were reported by another study, where they found a lack of statistical difference among diastolic blood pressure, systolic blood pressure, and heart rate in participants in a rest group $(n=20)$ as well as a musical intervention group $(n=50)$ [76]. LF was used to describe the sympathetic activity and was of positive relevance with anxiety, however, HF indicated parasympathetic activity [77]. Furthermore, the LF/HF ratio evaluated the quantity of sympathetic balance to some extent [78], as well as a type of evaluation index concerning heart rate variability [79]. Low LF/HF ratio values indicate strong parasympathetic activity, whereas high values show strong sympathetic activity. Studies in other fields of surgery demonstrated similar ratios as this study $[39,78]$. Other holistic studies reported that musical interventions decreased physiological stress parameters and perioperative stress hormones. These results were not supported by powerful evidence [61, 80]. Nevertheless, another article considered only sparse evidence regarding the effectiveness of music in blood pressure, heart rate, and respiratory rate during the preoperative, postoperative, or intraoperative periods [20]. Surgery may influence the cardiovascular system by stimulating the sympathetic nervous system like in elevated blood pressure, heart rate, and oxygen saturation [81]. Additional research in this regard could provide the relevant data in these fields.

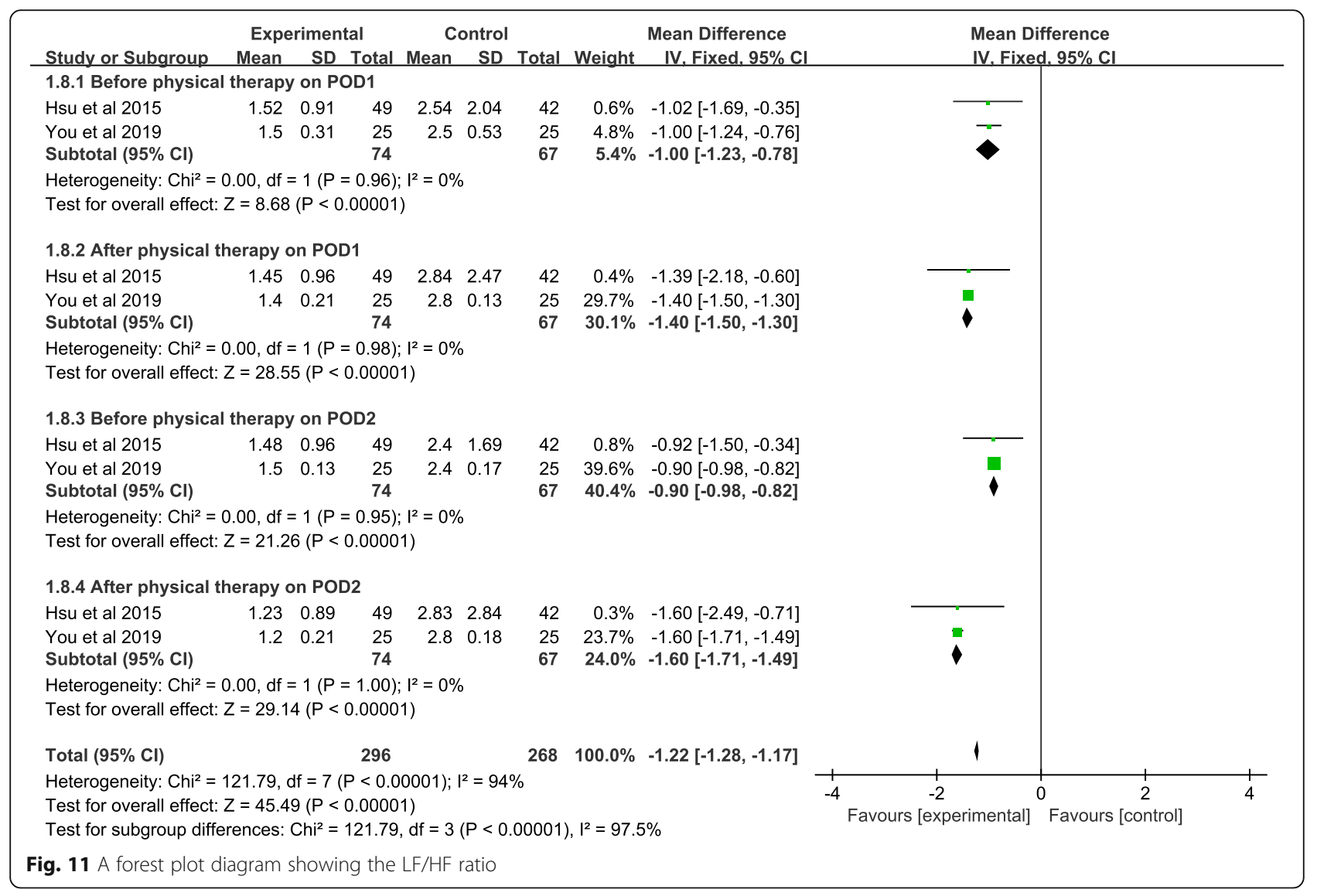


Table 4 Results subgroup analysis of others

\begin{tabular}{|c|c|c|c|c|c|c|c|c|c|}
\hline \multirow[t]{2}{*}{ Clinical results } & \multirow[t]{2}{*}{ Studies } & \multicolumn{3}{|c|}{ Number of participants } & \multicolumn{5}{|c|}{ Incidence } \\
\hline & & Total & Music & $\overline{\text { Control }}$ & $\bar{P}$ & MD & $95 \% \mathrm{Cl}$ & Heterogeneity $\mathrm{P}\left(I^{2}\right)$ & Model \\
\hline \multicolumn{10}{|l|}{ Respiratory rate } \\
\hline Headphones & 2 & 116 & 58 & 58 & 0.76 & 0.06 & -0.35 to 0.48 & $0.80(0 \%)$ & Fixed \\
\hline Non-headphones & 1 & 30 & 15 & 15 & 0.22 & 0.14 & -0.88 to 1.17 & NS & NS \\
\hline Including FPM & 1 & 60 & 30 & 30 & 0.58 & 0.15 & -0.39 to 0.69 & NS & NS \\
\hline Not including FPM & 2 & 86 & 43 & 43 & 0.98 & -0.01 & -0.52 to 0.51 & $0.62(0 \%)$ & Fixed \\
\hline \multicolumn{10}{|l|}{ Heart rate } \\
\hline Headphones & 3 & 207 & 107 & 100 & 0.74 & 0.34 & -1.68 to 2.37 & $0.79(0 \%)$ & Fixed \\
\hline Non-headphones & 1 & 30 & 15 & 15 & 1.00 & -0.02 & -6.36 to 6.33 & NS & NS \\
\hline Including FPM & 1 & 60 & 30 & 30 & 0.35 & -2.86 & - 8.90 to 3.18 & NS & NS \\
\hline Not including FPM & 3 & 187 & 92 & 95 & 0.52 & 0.67 & -1.37 to 2.71 & $0.95(0 \%)$ & Fixed \\
\hline \multicolumn{10}{|l|}{ Pain severity } \\
\hline Headphones & 4 & 182 & 91 & 91 & 0.28 & -0.74 & -2.09 to 0.60 & $<0.00001(83 \%)$ & Random \\
\hline Non-headphones & 2 & 62 & 31 & 31 & 0.96 & -0.02 & -0.59 to 0.56 & $0.18(42 \%)$ & Fixed \\
\hline Including FPM & 4 & 157 & 79 & 78 & 0.12 & -1.05 & -2.37 to 0.28 & $<0.00001(82 \%)$ & Random \\
\hline Not including FPM & 2 & 86 & 43 & 43 & 0.42 & 0.23 & -0.33 to 0.78 & $0.48(0 \%)$ & Fixed \\
\hline \multicolumn{10}{|l|}{ Oxygen saturation } \\
\hline Including FPM & 1 & 60 & 30 & 30 & 0.54 & -0.31 & -1.31 to 0.69 & NS & NS \\
\hline Not including FPM & 1 & 56 & 28 & 28 & 0.21 & -0.90 & -0.90 to 0.51 & NS & NS \\
\hline \multicolumn{10}{|l|}{ Blood pressure } \\
\hline Headphones & 1 & 60 & 30 & 30 & 0.48 & -1.47 & -5.56 to 2.26 & NS & NS \\
\hline Non-headphones & 1 & 30 & 15 & 15 & 0.34 & -3.71 & 11.27 to 3.86 & NS & NS \\
\hline
\end{tabular}

$M D$ mean difference, $C l$ confidence interval, FPM fast-paced music, NS not state

\section{Subgroup analysis of others}

During data processing, various modes of musical interventions were identified, which led to high heterogeneity in the systematic review. Consequently, subgroup analyses were performed to assess the effects of music via headphones and fast-paced music between the two groups in order to determine a more reasonable and standard way of musical intervention. Due to the limited number of studies, this study failed to obtain a definite conclusion. More than one study demonstrated large discrepancies in the studied intervention type, outcome measures used, outcomes measured, duration, timing of intervention participants, and choices of music [82, 83]. Participants with headphones in the control group reported that headphones relieved anxiety by shielding background noise in the postoperative recovery room [84]. In addition, headphones promoted privacy, avoiding external noise, reducing noise-related mental fatigue, and more $[22,85,86]$. The music preferences of patients were a key factor when opting for musical intervention. This involved a patient-centered practice by allowing patients to choose the type of rhythm, which may achieve better results [87]. Interestingly, a previous study found that melodies were preferred to rhythms as melodies could alter the activity level of the adrenergic system [88]. Due to this study's small sample size, the results should be interpreted with caution as additional related studies are undertaken.

\section{Limitations}

This research is the first meta-analysis and systematic review that appraises the effectiveness of musical interventions for TKR patients. However, various limitations were present in this study. Due to heterogeneity in the intensity, duration, type of music, and type of the interventions, few probabilities in acquiring abundant data exist in this study, which increased the difficulty in generalizing the findings for this population. In addition, high-quality studies may have been overlooked. Moreover, the conclusions may have been affected as some of the included studies had noticeable methodological shortcomings. Additionally, the studies in the present meta-analysis had unclear or high risk-of-bias ratings, which may cause the conclusion to lack persuasiveness. However, despite these limitations, a comprehensive review was given to estimate the effect of musical 
interventions in improving short-term pain outcomes following TKR, while determining meaningful methodological instructions for future studies.

\section{Conclusion}

Musical interventions fail to demonstrate an obvious effect in improving short-term pain outcomes following TKR. This review also repeatedly emphasizes the need for additional evidence in exploring the standardization of musical interventions (including musical type, outcome measures used, outcomes measured, duration, timing, and headphones or players) in improving pain outcomes after TKR, paving the way for future studies. The number and quality of the included studies were limited; consequently, studies with properly randomized techniques and larger sample sizes are anticipated.

\section{Abbreviations}

Cl: Confidence interval; CPM: Continuous passive motion; LOS: Length of stay; LF/HF: Low-frequency/high-frequency ratio; MD: Mean difference; NS: Not stated; Intra-op: Intraoperative; POD: Postoperative day; Preop: Preoperative; PRISMA: Preferred Reporting Items for Systematic Reviews and Meta-Analyses; PT: Physical therapy; Post-op: Postoperative; RCTs: Randomized controlled trials; RD: Risk difference; RevMan: Review Manager; ROM: Range of motion; TKA: Total knee arthroplasty; TKR: Total knee replacement; VAS: Visual analog scale

\section{Acknowledgements}

We are very grateful for many helpful comments by an anonymous reviewer on an earlier version of this manuscript.

\section{Patient and public involvement}

No patient involved

\section{Declarations}

The first author is responsible for misconduct in the research and writing process. The original images, data (including computer database) records and samples involved in the paper have been saved, Shared and destroyed in accordance with relevant regulations and can accept verification.

\section{Authors' contributions}

RGY, YGZ, and EYF performed study design. FTL, ZLL, LQL, LLX, HYW, YTH, $C L W$, and WLW participated in literature search and data extraction. RGY, $E Y F$, and YGZ were in charge of quality assessment and statistical analysis. RGY was responsible for manuscript review. All authors read and approved the final manuscript.

\section{Funding}

There is no funding for this article.

\section{Availability of data and materials}

We state that all data generated during the present study are included in this article.

\section{Ethics approval and consent to participate}

Not applicable

\section{Consent for publication}

Not applicable

\section{Competing interests}

The authors declare no competing interests.
Received: 13 August 2020 Accepted: 1 October 2020

Published online: 09 October 2020

\section{References}

1. Grant AE, Schwenk ES, Torjman MC, Hillesheim R, Chen AF. Postoperative analgesia in patients undergoing primary or revision knee arthroplasty with adductor canal block. Anesthesiology and pain medicine. 2017;7(3):e46695.

2. Tang $Y$, Tang $X$, Wei $Q H$, Zhang $H$. Intrathecal morphine versus femoral nerve block for pain control after total knee arthroplasty: a meta-analysis. J Orthop Surg Res. 2017;12:8

3. Vasarhelyi EM, Petis SM. Use of national joint registries to evaluate a new knee arthroplasty design. J Arthroplast. 2020;35(2):413-6.

4. Cram P, Lu X, Kates SL, Singh JA, Li Y, Wolf BR. Total knee arthroplasty volume, utilization, and outcomes among Medicare beneficiaries, 1991-2010. Jama. 2012;308(12):1227-36.

5. Kurtz S, Ong K, Lau E, Mowat F, Halpern M. Projections of primary and revision hip and knee arthroplasty in the United States from 2005 to 2030. J Bone Joint Surg Am. 2007:89(4):780-5.

6. Singelyn FJ, Deyaert M, Joris D, Pendeville E, Gouverneur JM. Effects of intravenous patient-controlled analgesia with morphine, continuous epidural analgesia, and continuous three-in-one block on postoperative pain and knee rehabilitation after unilateral total knee arthroplasty. Anesth Analg. 1998;87(1):88-92.

7. Kehlet H, Dahl JB. Anaesthesia, surgery, and challenges in postoperative recovery. Lancet (London, England). 2003;362(9399):1921-8.

8. Essving P, Axelsson K, Aberg E, Spannar H, Gupta A, Lundin A. Local infiltration analgesia versus intrathecal morphine for postoperative pain management after total knee arthroplasty: a randomized controlled trial. Anesth Analg. 2011;113(4):926-33.

9. Dihle A, Helseth S, Kongsgaard UE, Paul SM, Miaskowski C. Using the American Pain Society's patient outcome questionnaire to evaluate the quality of postoperative pain management in a sample of Norwegian patients. The journal of pain : official journal of the American Pain Society. 2006:7(4):272-80.

10. Sinatra RS, Torres J, Bustos AM. Pain management after major orthopaedic surgery: current strategies and new concepts. The Journal of the American Academy of Orthopaedic Surgeons. 2002;10(2):117-29.

11. Vissers MM, Bussmann JB, Verhaar JA, Busschbach JJ, Bierma-Zeinstra SM, Reijman M. Psychological factors affecting the outcome of total hip and knee arthroplasty: a systematic review. Semin Arthritis Rheum. 2012;41(4): $576-88$

12. Pinto PR, Mclntyre T, Ferrero R, Almeida A, Araujo-Soares V. Risk factors for moderate and severe persistent pain in patients undergoing total knee and hip arthroplasty: a prospective predictive study. PLoS One. 2013;8(9):e73917.

13. Lindberg MF, Miaskowski C, RustoEn T, Rosseland LA, Cooper BA, Lerdal A. Factors that can predict pain with walking, 12 months after total knee arthroplasty. Acta Orthop. 2016;87(6):600-6.

14. Katz J, Seltzer Z. Transition from acute to chronic postsurgical pain: risk factors and protective factors. Expert Rev Neurother. 2009;9(5):723-44.

15. Li B, Wen Y, Liu D, Tian L. The effect of knee position on blood loss and range of motion following total knee arthroplasty. Knee surgery, sports traumatology, arthroscopy : official journal of the ESSKA. 2012:20(3):594-9.

16. Napier RJ, Bennett D, McConway J, Wilson R, Sykes AM, Doran E, O'Brien S, Beverland DE. The influence of immediate knee flexion on blood loss and other parameters following total knee replacement. The bone \& joint journal. 2014:96-b(2):201-9.

17. Moucha CS, Weiser MC, Levin EJ. Current Strategies in Anesthesia and Analgesia for Total Knee Arthroplasty. The Journal of the American Academy of Orthopaedic Surgeons. 2016;24(2):60-73.

18. Hyman RB, Feldman HR, Harris RB, Levin RF, Malloy GB. The effects of relaxation training on clinical symptoms: a meta-analysis. Nurs Res. 1989; 38(4):216-20.

19. Abraha I, Rimland JM, Trotta F, Pierini V, Cruz-Jentoft A, Soiza R, O'Mahony D, Cherubini A. Non-pharmacological interventions to prevent or treat delirium in older patients: clinical practice recommendations the SENATORONTOP Series. J Nutr Health Aging. 2016;20(9):927-36.

20. Nilsson $U$. The anxiety- and pain-reducing effects of music interventions: a systematic review. AORN J. 2008;87(4):780-807.

21. Cole LC, LoBiondo-Wood G. Music as an adjuvant therapy in control of pain and symptoms in hospitalized adults: a systematic review. Pain 
management nursing : official journal of the American Society of Pain Management Nurses. 2014;15(1):406-25.

22. McCaffrey R, Locsin RC. Music listening as a nursing intervention: a symphony of practice. Holist Nurs Pract. 2002;16(3):70-7.

23. Nilsson $U$. The anxiety-and pain-reducing effects of music interventions: a systematic review. AORN J. 2008;87(4):780-807.

24. Tam WW, Wong EL, Twinn SF. Effect of music on procedure time and sedation during colonoscopy: a meta-analysis. World J Gastroenterol. 2008; 14(34):5336-43.

25. Jeong GS, Kim MH. Effect of music therapy on anxiety, blood pressure, heart rate and glucose levels of patients undergoing surgery during spinal anesthesia. Journal of Korean Academy of Fundamentals of Nursing. 2015; 22(1):25-34.

26. Kuhlmann AY, Etnel JR, Roos-Hesselink JW, Jeekel J, Bogers AJ, Takkenberg JJ. Systematic review and meta-analysis of music interventions in hypertension treatment: a quest for answers. BMC Cardiovasc Disord. 2016; 16:69.

27. Good M, Stanton-Hicks M, Grass JA, Cranston Anderson G, Choi C, Schoolmeesters $L$, Salman A. Relief of postoperative pain with jaw relaxation, music and their combination. Pain. 1999;81(1-2):163-72.

28. Heiser RM, Chiles K, Fudge M, Gray SE. The use of music during the immediate postoperative recovery period. AORN J. 1997;65(4):777-85.

29. Hekmat HM, Hertel JB. Pain attenuating effects of preferred versus nonpreferred music interventions. Psychol Music. 1993;21(2):163-73.

30. Koch ME, Kain ZN, Ayoub C, Rosenbaum SH. The sedative and analgesic sparing effect of music. Anesthesiology. 1998;89(2):300-6.

31. Ikonomidou E, Rehnstrom A, Naesh O. Effect of music on vital signs and postoperative pain. AORN J. 2004;80(2):269-74 277-268.

32. Shertzer KE, Keck JF. Music and the PACU environment. Journal of perianesthesia nursing : official journal of the American Society of PeriAnesthesia Nurses. 2001;16(2):90-102.

33. Whale K, Wylde V, Beswick A, Rathbone J, Vedhara K, Gooberman-Hill R. Effectiveness and reporting standards of psychological interventions for improving short-term and long-term pain outcomes after total knee replacement: a systematic review. BMJ Open. 2019;9(12):e029742.

34. Lin CL, Hwang SL, Jiang P, Hsiung NH. Effect of Music Therapy on Pain After Orthopedic Surgery_A Systematic Review and Meta-Analysis. Pain Practice. 2019.

35. Sibanda A, Carnes D, Visentin D, Cleary M. A systematic review of the use of music interventions to improve outcomes for patients undergoing hip or knee surgery. J Adv Nurs. 2019;75(3):502-16.

36. Moher D, Liberati A, Tetzlaff J, Altman DG. Preferred reporting items for systematic reviews and meta-analyses: the PRISMA statement. PLoS Med. 2009;6(7):e1000097.

37. Cetinkaya F. Effect of Listening to Music on Postoperative Cognitive Function in Older Adults After Hip or Knee Surgery: A Randomized Controlled Trial. Journal of perianesthesia nursing : official journal of the American Society of PeriAnesthesia Nurses. 2019;34(5):919-28.

38. Antall GF, Kresevic D. The use of guided imagery to manage pain in an elderly orthopaedic population. Orthop Nurs. 2004;23(5):335-40.

39. Hsu CC, Chen SR, Lee PH, Lin PC. The effect of music listening on pain, heart rate variability, and range of motion in older adults after total knee replacement. Clin Nurs Res. 2019;28(5):529-47.

40. Hsu CC, Chen WM, Chen SR, Tseng YT, Lin PC. Effectiveness of music listening in patients with total knee replacement during CPM rehabilitation. Biological research for nursing. 2016;18(1):68-75.

41. Kang JG, Lee JJ, Kim DM, Kim JA, Kim CS, Hahm TS, Lee BD. Blocking noise but not music lowers bispectral index scores during sedation in noisy operating rooms. J Clin Anesth. 2008;20(1):12-6.

42. Keshmiri A, Wolf T, Wiech O, Benditz A, Grifka J, Springorum H. Einfluss der intraoperativen Schallprotektion auf postoperative Schmerzen. Schmerz. 2014;28(1):82-9.

43. Allred KD, Byers JF, Sole ML. The effect of music on postoperative pain and anxiety. Pain management nursing : official journal of the American Society of Pain Management Nurses. 2010;11(1):15-25.

44. Chen HJ, Chen TY, Huang CY, Hsieh YM, Lai HL. Effects of music on psychophysiological responses and opioid dosage in patients undergoing total knee replacement surgery. Japan journal of nursing science : JJNS. 2015;12(4):309-19.

45. Finlay KA, Wilson JA, Gaston P, Al-Dujaili EA, Power I. Post-operative pain management through audio-analgesia: Investigating musical constructs. Psychol Music. 2016;44(3):493-513.
46. Hooks HE. Effects of music intervention on the patient's perception of pain after knee replacement surgery; 2014.

47. Leonard $\mathrm{H}$. Live music therapy during rehabilitation after total knee arthroplasty: a randomized controlled trial. J Music Ther. 2019:56(1):61-89.

48. Simcock XC, Yoon RS, Chalmers P, Geller JA, Kiernan HA, Macaulay W. Intraoperative music reduces perceived pain after total knee arthroplasty: a blinded, prospective, randomized, placebo-controlled clinical trial. The journal of knee surgery. 2008;21(4):275-8.

49. Linna Y, Yuan L, Lingyun Z, Yan S: Effect of music therapy on CPM accepted in early stages after operation by patients with total knee arthroplasty, vol. 16; 2019.

50. Zeng C, Lane NE, Hunter D, Wei J, Choi H, McAlindon T, Li H, Lu N, Lei G, Zhang Y. Intra-articular corticosteroids and the risk of knee osteoarthritis progression: results from the Osteoarthritis Initiative. Osteoarthr Cartil. 2019; 27(6):855-62.

51. Puolakka PA, Rorarius MG, Roviola M, Puolakka TJ, Nordhausen K, Lindgren L. Persistent pain following knee arthroplasty. Eur J Anaesthesiol. 2010;27(5): 455-60.

52. Gomez-Cardero P, Rodriguez-Merchan EC. Postoperative analgesia in TKA: ropivacaine continuous intraarticular infusion. Clin Orthop Relat Res. 2010; 468(5):1242-7.

53. Kazak Bengisun Z, Aysu Salviz E, Darcin K, Suer H, Ates Y. Intraarticular levobupivacaine or bupivacaine administration decreases pain scores and provides a better recovery after total knee arthroplasty. J Anesth. 2010;24(5):694-9.

54. Safa B, Gollish J, Haslam L, McCartney CJ. Comparing the effects of single shot sciatic nerve block versus posterior capsule local anesthetic infiltration on analgesia and functional outcome after total knee arthroplasty: a prospective, randomized, double-blinded, controlled trial. J Arthroplast. 2014;29(6):1149-53.

55. Elmallah RK, Cherian JJ, Pierce TP, Jauregui JJ, Harwin SF, Mont MA. New and common perioperative pain management techniques in total knee arthroplasty. The journal of knee surgery. 2016;29(2):169-78.

56. Ekman EF, Koman LA. Acute pain following musculoskeletal injuries and orthopaedic surgery: mechanisms and management. Instr Course Lect. 2005;54:21-33.

57. Cepeda MS, Carr DB, Lau J, Alvarez H. WITHDRAWN: Music for pain relief. The Cochrane database of systematic reviews. 2013;10:Cd004843.

58. Ebneshahidi A, Mohseni M. The effect of patient-selected music on early postoperative pain, anxiety, and hemodynamic profile in cesarean section surgery. Journal of alternative and complementary medicine (New York, NY) 2008;14(7):827-31.

59. Good M, Anderson GC, Ahn S, Cong X, Stanton-Hicks M. Relaxation and music reduce pain following intestinal surgery. Res Nurs Health. 2005;28(3): 240-51.

60. Hook L, Songwathana P, Petpichetchian W. Music therapy with female surgical patients: effect on anxiety and pain. Pacific Rim International Journal of Nursing Research. 2008;12(4):259-71.

61. Tse MM, Chan MF, Benzie IF. The effect of music therapy on postoperative pain, heart rate, systolic blood pressures and analgesic use following nasal surgery. Journal of pain \& palliative care pharmacotherapy. 2005;19(3):21-9.

62. Zhang $X L$, Cheng T, Zeng BF. Experts' consensus on minimally invasive surgery for total joint arthroplasty. Orthop Surg. 2011;3(3):147-51.

63. Melzack R. Pain and the neuromatrix in the brain. J Dent Educ. 2001;65(12): 1378-82.

64. Melzack R, Wall PD. Pain mechanisms: a new theory. Science (New York, NY). 1965;150(3699):971-9.

65. Smith JC, Joyce CA. Mozart versus new age music: relaxation states, stress, and ABC relaxation theory. J Music Ther. 2004;41(3):215-24.

66. Argenson JN, Parratte S, Ashour A, Komistek RD, Scuderi GR. Patientreported outcome correlates with knee function after a single-design mobile-bearing TKA. Clin Orthop Relat Res. 2008;466(11):2669-76.

67. Eisenman A, Cohen B. Music therapy for patients undergoing regional anesthesia. AORN J. 1995;62(6):947-50.

68. Chanda ML, Levitin DJ. The neurochemistry of music. Trends Cogn Sci. 2013; 17(4):179-93.

69. Denis M, Moffet H, Caron F, Ouellet D, Paquet J, Nolet L. Effectiveness of continuous passive motion and conventional physical therapy after total knee arthroplasty: a randomized clinical trial. Phys Ther. 2006:86(2):174-85.

70. Glassner PJ, Slover JD, Bosco JA 3rd, Zuckerman JD. Blood, bugs, and motion - what do we really know in regard to total joint arthroplasty? Bulletin of the NYU hospital for joint diseases. 2011;69(1):73-80. 
71. Lenssen TA, van Steyn MJ, Crijns YH, Waltje EM, Roox GM, Geesink RJ, van den Brandt PA, De Bie RA. Effectiveness of prolonged use of continuous passive motion (CPM), as an adjunct to physiotherapy, after total knee arthroplasty. BMC Musculoskelet Disord. 2008;9:60

72. Lucas B. Total hip and total knee replacement: postoperative nursing management. British journal of nursing (Mark Allen Publishing). 2008;17(22): $1410-4$.

73. Brosseau L, Milne S, Wells G, Tugwell P, Robinson V, Casimiro L, Pelland L, Noel MJ, Davis J, Drouin H. Efficacy of continuous passive motion following total knee arthroplasty: a metaanalysis. J Rheumatol. 2004;31(11):2251-64.

74. Harvey LA, Brosseau L, Herbert RD. Continuous passive motion following total knee arthroplasty in people with arthritis. The Cochrane database of systematic reviews. 2010;3:Cd004260.

75. Wright WL. Management of mild-to-moderate osteoarthritis: effective intervention by the nurse practitioner. J Nurse Pract. 2008:4(1):25-34.

76. Sendelbach SE, Halm MA, Doran KA, Miller EH, Gaillard P. Effects of music therapy on physiological and psychological outcomes for patients undergoing cardiac surgery. J Cardiovasc Nurs. 2006;21(3):194-200.

77. Tang S, Lo L, Yen M, Tsai W. The relationship between anxiety and heart rate variability in patients receiving cardiac catheterization. Journal of Evidence-Based Nursing. 2006;2:53-62.

78. Peng SM, Koo M, Yu ZR. Effects of music and essential oil inhalation on cardiac autonomic balance in healthy individuals. Journal of alternative and complementary medicine (New York, NY). 2009;15(1):53-7.

79. Chen G, Kuo C, Lo H. Heart rate variablility. Journal of Emergency and Critical Care Medicine. 2000;11(2):47-58

80. Nilsson U, Unosson M, Rawal N. Stress reduction and analgesia in patients exposed to calming music postoperatively: a randomized controlled trial. Eur J Anaesthesiol. 2005;22(2):96-102.

81. Pasero C, Paice JA, McCaffery M. Basic mechanisms underlying the causes and effects of pain. Pain: clinical manual. 1999:15-34.

82. Bradt J, Dileo C, Shim M. Music interventions for preoperative anxiety. The Cochrane database of systematic reviews. 2013;6:Cd006908

83. Yinger OS, Gooding LF. A systematic review of music-based interventions for procedural support. J Music Ther. 2015;52(1):1-77.

84. Lee OK, Chung YF, Chan MF, Chan WM. Music and its effect on the physiological responses and anxiety levels of patients receiving mechanical ventilation: a pilot study. J Clin Nurs. 2005;14(5):609-20.

85. Evans D. The effectiveness of music as an intervention for hospital patients: a systematic review. J Adv Nurs. 2002;37(1):8-18.

86. MacDonald RA, Mitchell LA, Dillon T, Serpell MG, Davies JB, Ashley EA. An empirical investigation of the anxiolytic and pain reducing effects of music. Psychol Music. 2003;31(2):187-203.

87. Daveson BA. Music therapy and childhood cancer: Goals, methods, patient choice and control during diagnosis, intensive treatment, transplant and palliative care. Music Ther Perspect. 2001;19(2):114-20.

88. Yamamoto T, Ohkuwa T, Itoh H, Kitoh M, Terasawa J, Tsuda T, Kitagawa S, Sato Y. Effects of pre-exercise listening to slow and fast rhythm music on supramaximal cycle performance and selected metabolic variables. Arch Physiol Biochem. 2003;111(3):211-4.

\section{Publisher's Note}

Springer Nature remains neutral with regard to jurisdictional claims in published maps and institutional affiliations.

\section{Ready to submit your research? Choose BMC and benefit from:}

- fast, convenient online submission

- thorough peer review by experienced researchers in your field

- rapid publication on acceptance

- support for research data, including large and complex data types

- gold Open Access which fosters wider collaboration and increased citations

- maximum visibility for your research: over $100 \mathrm{M}$ website views per year

At $\mathrm{BMC}$, research is always in progress.

Learn more biomedcentral.com/submissions 